This is a self-archived version of an original article. This version may differ from the original in pagination and typographic details.

Author(s): Nieminen, Mika; Heimonen, Kari; Tohmo, Timo

Title: Current Accounts and Coordination of Wage Bargaining

Year: 2019

Version: Accepted version (Final draft)

Copyright: (c) Springer Science+Business Media, LLC, part of Springer Nature 2018

Rights: In Copyright

Rights url: http://rightsstatements.org/page//nC/1.0/?language=en

Please cite the original version:

Nieminen, M., Heimonen, K., \& Tohmo, T. (2019). Current Accounts and Coordination of Wage Bargaining. Open Economies Review, 30(2), 319-341. https://doi.org/10.1007/s11079-0189511-2 


\title{
Current Accounts and Coordination of Wage Bargaining*
}

\author{
Mika Nieminen $\quad$ Kari Heimonen $\quad$ Timo Tohmo
}

June 27, 2018

\begin{abstract}
This study provides novel evidence on the impact of labor market institutions on current account dynamics. Our results suggest that a high degree of coordination of wage bargaining has a positive effect on the current account balance over the long run. This result is not driven entirely by wage moderation induced by centralized wage setting. We also provide robust evidence that a high degree of coordination of wage bargaining is associated with a slower current account adjustment toward its long-run equilibrium. This result seems theoretically plausible; the aggregate shocks in the exporting sector are largely driven by idiosyncratic shocks and the presence of idiosyncratic shocks increases the importance of labor market flexibility. Overall, our analysis of the impact of labor market institutions on current account dynamics complements the existing empirical current account literature focused on macroeconomic and financial measures.
\end{abstract}

Keywords: Current account balance; Current account dynamics; Coordination of wage bargaining; Exchange rate adjustment

JEL classification: F21; F32; F41

\footnotetext{
${ }^{*}$ We thank two anonymous referees, Ansgar Belke, Stephen G. Hall, Sercan Eraslan, Niku Määttänen, Tomi Kortela and the other participants at the $21^{\text {st }}$ Annual International Conference on Macroeconomic Analysis and International Finance, FDPE Macroeconomics Workshop I/2016, Finnish Economic Association XXXVIII Annual Meeting, BOFIT seminar at the Bank of Finland, as well as Zuzana Fungáčová, Juho Jokinen, Mika Maliranta and Matthias Strifler for useful comments and suggestions. Mika Nieminen acknowledges financial support from the OP Group Research Foundation, the Alfred Kordelin Foundation and Bank of Finland Institute for Economies in Transition. This study is part of the work of the JSBE Research Group on International Macro and Finance (JyIMaF) which acknowledges financial support from the OP Group Research Foundation.

Corresponding author: Mika Nieminen, orcid.org/0000-0002-9969-1803. Jyväskylä University School of Business and Economics, University of Jyväskylä, Finland. E-mail: mika.p.nieminen@jyu.fi. Tel.: +358504016350.
}

Kari Heimonen, orcid.org/0000-0002-7783-8018. Jyväskylä University School of Business and Economics, University of Jyväskylä, Finland.

Timo Tohmo, orcid.org/0000-0002-1189-2257. Jyväskylä University School of Business and Economics, University of Jyväskylä, Finland. 


\section{Introduction}

Academic and policy debates have devoted considerable attention to global current account imbalances and intra-euro area imbalances over the past ten years. The many studies on medium-term determinants of current account balances (e.g., Chinn and Prasad, 2003; Chinn and Ito, 2007; Gruber and Kamin, 2007; Ca' Zorzi et al., 2012) concentrate on macroeconomic factors such as GDP per capita, government budget balance, or institutional variables that measure differences in financial development and political stability. A closely related strand of the literature considers determinants of the rate of current account adjustment (e.g., Chinn and Wei, 2013; Ghosh et al., 2013). These studies are largely limited to examining the role of exchange rate regimes. Given that the type and degree of wage-bargaining coordination affects macroeconomic performance (for reviews, see Flanagan, 1999; Aidt and Tzannatos, 2010), the lack of empirical studies of the role of labor market institutions in current account dynamics is striking. For example, EMU member countries, unable to use exchange rate adjustment as a policy instrument after adopting the euro, must rely increasingly on labor market institutions in economic adjustment.

We argue that factors related to labor market institutions such as the degree of wage-bargaining coordination can significantly affect both the current account balance and speed of adjustment of the current account toward its long-run equilibrium.

Collective wage bargaining may take place at firm level, by industry, or on a national scale. Although it is not easy to classify countries by this criterion, the substantial differences across countries in the degree of coordination of wage bargaining is quite apparent. Northern European countries tend to use centralized bargaining, while English-speaking countries, except Ireland, have preferred more fragmented approaches. 
(Cahuc et al., 2014, pp. 408-410.) If the wage-bargaining structure affects costcompetitiveness of an economy (see Calmfors and Driffill, 1988; Carlin and Soskice, 2006, p. 114), it is plausible to assume that the wage-bargaining structure also affects the level of the current account balance.

For open economies, Traxler and Brandl (2012) propose that the macro effects of bargaining on price competitiveness depend on how well the bargain takes into account inter-sectoral productivity differentials. Industry-level bargaining is superior where the exposed sector dominates wage coordination. They find that the wage-bargaining structure has a statistically significant effect on the growth rate of nominal labor cost and current account balance. With respect to current account surplus, they specifically argue that exposed-sector pattern bargaining outperforms other wage bargaining structures. Du and Liu (2015) assert that labor market flexibility affects the real exchange rate. Both papers suggest that labor market institutions such as the degree of coordination of wage bargaining may affect the current account balance. The distinction of Traxler and Brandl (2012) of productivity differences between exposed and sheltered sectors, however, does not address the real-world issue of large productivity differentials between individual firms within the tradable sector (e.g., Syversen, 2011; Bernard et al., 2012).

An economy can absorb shocks by means of current account adjustment. If aggregate-level shocks are the sole drivers of productivity growth, adjustment should be faster in centralized-bargaining regimes than in countries that use industry-level bargaining (see Aidt and Tzannatos, 2008, pp. 263-264; Carlin and Soskice, 2006, pp. 748-749). Canals et al. (2007), Del Rosal (2013) and Freund and Pierola (2015) all find, 
however, that a large fraction of aggregate volatility in exports or net exports results from firm-specific shocks.

Typically, highly centralized bargaining systems do a poorer job at accounting for conditions of individual firms. The groundbreaking work of Ju et al. (2014) provides the first microfoundations for understanding cross-country heterogeneity in the current account adjustment rate. They show that an economy's response to a shock involves a combination of intertemporal trade (current account adjustment) and intra-temporal trade (goods trade). Their theoretical model and empirical results indicate that labor market rigidities make the adjustment of current account toward its long-run equilibrium level slower.

Cuñat and Melitz (2012) build a theoretical model that highlights the importance of labor market flexibility as volatility (variance of firm-specific shocks in a sector) increases. Labor market flexibility is a source of comparative advantage in highvolatility sectors. They also provide empirical evidence consistent with their model. The exports of countries with relatively flexible labor markets are biased toward highvolatility sectors.

If a government or central organizations have a strong preference for wage moderation, centralized wage bargaining might have a positive effect on the current account balance by enhancing cost-competitiveness. Correspondingly, if a large fraction of aggregate volatility in exports results from firm-specific shocks, centralized wage bargaining might have a negative effect on the speed of current account adjustment. Firm-specific competitiveness is most easily sustained by firm-level wage bargaining. 
Our empirical results show that a high degree of coordination of wage bargaining has a positive effect on the current account balance in the long run and a negative effect on the speed of adjustment of the current account toward its long-run equilibrium. ${ }^{1}$

The remainder of the paper proceeds as follows. Section 2 provides descriptions of the data and empirical methodology. Section 3 is a presentation of our results on determinants of the current account balance and rate of current account reversion. Section 4 includes conclusions and discussion.

\section{Data and empirical methodology}

\subsection{Data}

Our sample consists of 46 countries, 35 of which are advanced economies according to the IMF's country classification. The data on the degree of coordination of wage bargaining are taken from the Database on Institutional Characteristics of Trade Unions, Wage Setting, State Intervention and Social Pacts (ICTWSS), the most widely used data source on wage-bargaining coordination (see details in Visser, 2013). The country coverage of the ICTWSS database sets a limit to the number of countries in our sample. The sample period varies from country to country. The countries surveyed and sample periods appear in Tables A2-A3 of the Appendix.

Visser (2013) says that the variable measuring coordination of wage setting measures the degree, rather than type, of coordination. ${ }^{2}$ The degree of coordination of wage bargaining and the predominant level at which wage bargaining takes place do not

\footnotetext{
${ }^{1}$ The data on the degree of coordination of wage bargaining are from the Database on Institutional Characteristics of Trade Unions, Wage Setting, State Intervention and Social Pacts (ICTWSS), the most widely used data source on wage bargaining coordination. See section 2.1 for a more detailed description of the data.

${ }^{2}$ We call this variable "Coordination of wage bargaining." 
necessarily go hand in hand. While full centralization implies full coordination, fully decentralized bargaining can be highly coordinated. In the case of intermediate coordination, the variable measuring the degree of coordination of wage bargaining does not take into account which sector dominates pay coordination (pattern bargaining).

Descriptive statistics for the sample are provided in Table 1. The ICTWSS database groups degree of coordination in wage bargaining into five categories: $1=$ fragmented firm-level wage bargaining, 2 = mixed industry and firm-level bargaining, 3 $=$ informal centralization, $4=$ centralized bargaining without peace obligation, and $5=$ centralized bargaining with peace obligation. Since the degree of coordination of wage bargaining is not measured on the interval scale but on the ordinal scale, we mostly use the mode of the sample period for the wage-bargaining coordination variable and model different degrees of coordination of wage bargaining with a set of binary dummy variables. If we include the mode of coordination of wage bargaining in lieu of a set of binary dummy variables, we treat coordination of wage bargaining as a continuous variable and assume that the successive categories of the degree of coordination of wage bargaining are equally spaced. ${ }^{3}$ Models (4)-(5) in the panel regressions of current account balance and models (14)-(23) in the one-step procedure to obtain the rate of current account reversion use annual observations of the degree of coordination of wage bargaining rather than mode of coordination.

The set of control variables for the current account regressions is derived from the current account literature (e.g., Chinn and Prasad, 2003). It includes GDP per capita,

\footnotetext{
${ }^{3}$ We apply this latter approach in section 3.1 in models (3) and (5), as well as in section 3.2 in models (13), (19) and (25). We will show in sections 3.1 and 3.2 that our results are insensitive to whether we treat the coordination of wage bargaining as continuous or not.
} 
budget balance, old dependency ratio, a variable measuring institutional quality ${ }^{4}$ and the lagged net foreign asset position. The set of control variables for the current account adjustment regressions is derived from Ju et al. (2014, Tables 3-4), Chinn and Wei (2013, Tables 5-11), and Ghosh et al. (2013, Table 3). It includes GDP per capita in the year 2000, financial openness index, trade openness and real GDP per capita growth. ${ }^{5}$

Table 1. Descriptive statistics of the sample

\begin{tabular}{|c|c|c|c|c|c|c|}
\hline Variable & Units & Mean & Min & Max & $\begin{array}{l}\text { Std. } \\
\text { dev. }\end{array}$ & $\begin{array}{l}\text { share of } \\
\text { over time } \\
\text { variance }\end{array}$ \\
\hline $\begin{array}{l}\text { Current account } \\
\text { balance }\end{array}$ & ratio to GDP & -0.012 & -0.272 & 0.286 & 0.055 & 0.592 \\
\hline $\begin{array}{l}\text { Coordination of } \\
\text { wage bargaining }\end{array}$ & $\begin{array}{l}\text { index, from } 1 \text { (fragmented } \\
\text { firm-level) to } 5 \text { (centralized) }\end{array}$ & 2.806 & 1.000 & 5.000 & 1.323 & 0.316 \\
\hline GDP per capita & in tens of thousands of euros & 2.560 & 0.038 & 9.159 & 1.674 & 0.180 \\
\hline Budget balance & ratio to GDP & -0.024 & -0.208 & 0.161 & 0.038 & 0.501 \\
\hline $\begin{array}{l}\text { Old dependency } \\
\text { ratio }\end{array}$ & ratio & 0.188 & 0.053 & 0.375 & 0.062 & 0.107 \\
\hline $\begin{array}{l}\text { Democratic } \\
\text { accountability }\end{array}$ & $\begin{array}{l}\text { index, from } 1 \text { (poor) to } 6 \\
\text { (good) }\end{array}$ & 5.308 & 1.000 & 6.000 & 1.013 & 0.353 \\
\hline NFA & ratio to GDP & -0.158 & -1.655 & 2.556 & 0.422 & 0.354 \\
\hline $\begin{array}{l}\text { Financial } \\
\text { openness }\end{array}$ & $\begin{array}{l}\text { index, scaled between } \\
-1.87 \text { (low) and } 2.44 \text { (high) }\end{array}$ & 1.033 & -1.864 & 2.439 & 1.475 & 0.483 \\
\hline $\begin{array}{l}\text { Trade } \\
\text { openness }\end{array}$ & ratio to GDP & 0.712 & 0.077 & 4.304 & 0.585 & 0.073 \\
\hline $\begin{array}{l}\text { GDP per capita } \\
\text { growth }\end{array}$ & annual growth rate & 0.024 & -0.146 & 0.138 & 0.032 & 0.842 \\
\hline $\begin{array}{l}\text { Exchange rate } \\
\text { stability }\end{array}$ & $\begin{array}{l}\text { index, scaled between } 0.00 \\
\text { (low) and } 1.00 \text { (high) }\end{array}$ & 0.509 & 0.012 & 1.000 & 0.272 & 0.595 \\
\hline
\end{tabular}

\footnotetext{
${ }^{4}$ We tested several variables from the Political Risk Services' International Country Risk Guide. The variable "Democratic accountability" had the highest level of statistical significance in our regression models.

${ }^{5}$ We also test dummy variables for EMU-12 countries and advanced economies. In section 3.2.4 we take into account exchange rate flexibility and its potential interaction effect with wage bargaining coordination.
} 


\subsection{Current account regressions}

To answer our first research question: "Does the degree of coordination of wage bargaining have an effect on the current account balance in the long run?" we run both cross-sectional regressions with multi-year averages and panel data regression with annual observations. These are standard methodologies in the current account literature (e.g., Chinn and Prasad, 2003).

For models (1)-(3), we estimate the following cross-sectional regression model by the OLS estimator:

$\overline{C A}_{i}=\alpha+\gamma_{j} \sum_{j=1}^{k} \operatorname{Coord}_{j i}+\boldsymbol{x}_{i}^{\prime} \boldsymbol{\delta}+\varepsilon_{i}$

where the dependent variable is the long-run current account balance (ratio to GDP) ${ }^{6}, \alpha$ is an intercept, Coord $\mathrm{ji}_{\mathrm{i}}$ is a binary variable for coordination of wage bargaining in country i in regime $\mathrm{j}, \mathbf{x}_{\mathrm{i}}$ is a column vector including all control variables for country $\mathrm{i}$, and $\varepsilon_{\mathrm{i}}$ is a residual.

For models (4)-(5), we estimate the following panel data regression model by the pooled OLS estimator:

$C A_{i t}=\alpha+\mu_{t}+\gamma_{j} \sum_{j=1}^{k} \operatorname{Coord}_{j i t}+\boldsymbol{x}_{i t}^{\prime} \boldsymbol{\delta}+\varepsilon_{i t}$

\footnotetext{
${ }^{6}$ The long-run current account balances refer to the country-specific mean over the sample period. The sample period varies slightly from country to country (see Table A2 in the Appendix).
} 
where the dependent variable is current account balance (ratio to GDP), $\alpha$ is an intercept, $\mu_{t}$ are time fixed effects, Coord $\mathrm{jit}_{\mathrm{j}}$ measures the degree of coordination of wage bargaining, $\mathbf{x}_{\mathrm{it}}$ is a column vector including all explanatory variables for country $\mathrm{i}$ in period $\mathrm{t}$, and $\varepsilon_{\mathrm{it}}$ is a residual. In order to understand cross-country variation in current account, including country fixed effects would undermine much of the economically meaningful aspects of the econometric analysis (Chinn and Prasad, 2003, pp. 66-68). Hence, it has become standard in the current account literature to use the pooled OLS estimator.

\subsection{Current account adjustment regressions}

To answer our second research question: "Does the degree of coordination of wage bargaining have an effect on the speed of current account adjustment?" we apply two approaches. Our two-step procedure is adopted from Ju et al. (2014), while the one-step procedure follows, among others, Chinn and Wei (2013). Ju et al. (2014) note that, despite higher efficiency than the two-step procedure, the one-step procedure includes possible bias due to potential heterogeneity in steady-state current accounts across countries.

In the two-step procedure, we measure the country-specific speed of current account adjustment by estimating the following equation using the OLS estimator for each country:

$\Delta C A_{i t}=\beta_{0, i}+\beta_{1, i} C A_{i t-1}+\varepsilon_{i t}$, 
where $\Delta \mathrm{CA}_{\mathrm{it}}$ is the first difference of the current account balance (ratio to GDP) of country i in period t, $\beta_{0, i}$ and $\beta_{1, i}$ are country-specific coefficients, $C A_{i t-1}$ is the current account balance (ratio to GDP) of country $\mathrm{i}$ in period $\mathrm{t}-1$, and $\varepsilon_{\mathrm{it}}$ is a residual. Values of $\beta_{1, \mathrm{i}}$ close to minus one imply fast adjustment of the current account toward its long-run equilibrium, whereas values close to zero imply slow adjustment of the current account toward its long-run equilibrium. ${ }^{7}$ Potential serial correlation in the residual is eliminated by including higher orders of the lags of the dependent variable.

In the second stage of the two-step procedure for models (10)-(13), we estimate the following cross-sectional regression model by the OLS estimator:

$$
\beta_{1, i}=\alpha+\gamma_{j} \sum_{j=1}^{k} \operatorname{Coord}_{j i}+\boldsymbol{x}_{i}^{\prime} \boldsymbol{\delta}+\varepsilon_{i}
$$

where $\beta_{1, \mathrm{i}}$ is the speed of adjustment of the current account toward its long-run equilibrium (i.e. $\beta_{1, \mathrm{i}}$ in equation (3)) in country $\mathrm{i}, \alpha$ is an intercept, $\operatorname{Coord}_{\mathrm{ji}}$ is a binary variable for coordination of wage bargaining in country $i$ in regime $j, \mathbf{x}_{i}$ is a vector of control variables of country $i$, and $\varepsilon_{\mathrm{i}}$ is a residual.

Within the one-step procedure, we can measure the speed of current account adjustment by using two different approaches. The first approach with models (14)-(17) relies on estimating the following equation using the OLS estimator for each category of wage-bargaining coordination separately:

$C A_{i t}=\rho_{0}+\rho_{1} C A_{i t-1}+\varepsilon_{i t}$

\footnotetext{
${ }^{7}$ In the sample analyzed in Table 4 , the values of $\beta_{1}$ vary between -0.690 (Slovakia) and -0.055 (Germany).
} 
where $\mathrm{CA}_{i t}$ is the current account balance (ratio to GDP) of country $\mathrm{i}$ in period $t, \rho_{0}$ is an intercept, and $\varepsilon_{\mathrm{it}}$ is a residual. ${ }^{8}$ In the second approach for models (18)-(19), we estimate the following equation using the OLS estimator:

$C A_{i t}=\rho_{0}+\rho_{1} C A_{i t-1}+\gamma_{0 j} \sum_{j=1}^{k} \operatorname{Coord}_{j i t}+\gamma_{1 j}\left(\operatorname{CA}_{i t-1} \sum_{j=1}^{k} \operatorname{Coord}_{j i t}\right)+\varepsilon_{i t}$

where $\mathrm{CA}_{i t}$ is the current account balance (ratio to GDP) of country $\mathrm{i}$ in period $t, \rho_{0}$ is an intercept, Coord $\mathrm{jit}_{\mathrm{ji}}$ measures the degree of coordination of wage bargaining, and $\varepsilon_{\mathrm{it}}$ is a residual $^{9}$

We augment the two-step procedure with the one-step procedure for three reasons. First, it allows us to check if we produce the same results with respect to degree of coordination of wage bargaining as the two-step procedure. Second, it enables us to calculate a measure for the half-life of current account balance deviations for different degrees of wage-bargaining coordination. Third, it provides us a simple way to account for asymmetric effects. This implies that the current account adjustment may depend on the sign of the current account balance.

\section{Empirical results and discussion}

In section 3.1, we empirically test whether the degree of coordination of wage bargaining is related to the current account balance. In section 3.2, we examine the

\footnotetext{
${ }^{8}$ This approach is applied by Chinn and Wei (2013, Tables 1 and 3).

${ }^{9}$ This approach is applied by Chinn and Wei (2013, Table 2) and by Ghosh et al. (2013, Tables 1-2).
} 
association between the degree of coordination of wage bargaining and the speed of current account adjustment.

\subsection{Coordination of wage bargaining and current account balance}

Table 2 presents the results from estimating equations (1) and (2). Compared to our reference category for no coordination in wage bargaining (fragmented firm-level wage bargaining), a high degree of coordination in wage bargaining (centralized wage bargaining) has a positive effect on current account balances.

With regard to control variables, our models produce standard results. ${ }^{10}$ The result on the coordination of wage bargaining is statistically significant in both the crosssectional and panel data regressions. In models (2) and (4), we make a distinction between the two subcategories of centralized wage bargaining. ${ }^{11}$ In models (3) and (5), we include coordination of wage bargaining as a continuous variable. This identification assumes that the successive categories of the degree of coordination of wage bargaining are equally spaced. According to our estimations, the current account surplus (deficit) increases (decreases) monotonically with the degree of coordination of wage bargaining. The result is not driven by an outlier (see Figure A1 in the Appendix) and it is insensitive to whether we treat the coordination of wage bargaining as continuous or not. Furthermore, it is robust to including a set of control variables that has become standard in the current account literature. If we split the sample according to the IMF country classification and compare the two subsamples, we find that the positive relationship

\footnotetext{
${ }^{10}$ In addition to the variables listed, we also tested child dependency ratio, financial openness index and initial level of net foreign asset position. These were excluded, however, because they were statistically insignificant in all models.

${ }^{11}$ In the cross-sectional analysis, the "Centralized with peace obligation" category has only four countries, and for most cases, we lump the two subcategories of centralized wage bargaining together. Doing so does not affect the results.
} 
between coordination of wage bargaining and current account balance is stronger for advanced economies than emerging market and developing economies (see Figures S1$\mathrm{S} 2$ and Table $\mathrm{S} 1$ in the Electronic supplementary material). ${ }^{12}$

${ }^{12}$ See Table S2 in the Electronic supplementary material for the results including a dummy variable for the advanced economies. 
Table 2. Coordination of wage bargaining and current account balances ${ }^{13}$

\begin{tabular}{|c|c|c|c|c|c|}
\hline Variable & (1) & (2) & (3) & (4) & (5) \\
\hline \multicolumn{6}{|l|}{ Coordination of wage bargaining: } \\
\hline Industry and firm-level & $\begin{array}{l}0.007 \\
(0.011)\end{array}$ & $\begin{array}{l}0.007 \\
(0.011)\end{array}$ & & $\begin{array}{l}-0.000 \\
(0.009)\end{array}$ & \\
\hline Informal centralization & $\begin{array}{l}0.022 * \\
(0.012)\end{array}$ & $\begin{array}{l}0.022 * \\
(0.012)\end{array}$ & & $\begin{array}{l}0.017 * * \\
(0.008)\end{array}$ & \\
\hline Centralized bargaining: & $\begin{array}{l}0.026 * * * \\
(0.009)\end{array}$ & & & & \\
\hline $\begin{array}{l}\text { Centralized without } \\
\text { peace obligation }\end{array}$ & & $\begin{array}{l}0.025 * * \\
(0.010)\end{array}$ & & $\begin{array}{l}0.023 * * * \\
(0.008)\end{array}$ & \\
\hline $\begin{array}{l}\text { Centralized with } \\
\text { peace obligation }\end{array}$ & & $\begin{array}{l}0.028 * * \\
(0.012)\end{array}$ & & $\begin{array}{l}0.027 * * * \\
(0.009)\end{array}$ & \\
\hline $\begin{array}{l}\text { Coordination of wage bargaining } \\
\text { (1=Firm-level,..., } 5=\text { Centralized })\end{array}$ & & & $\begin{array}{l}0.008 * * * \\
(0.003)\end{array}$ & & $\begin{array}{l}0.008 * * * \\
(0.002)\end{array}$ \\
\hline GDP per capita & $\begin{array}{l}0.019 * * * \\
(0.003)\end{array}$ & $\begin{array}{l}0.019 * * * \\
(0.003)\end{array}$ & $\begin{array}{l}0.019 * * * \\
(0.002)\end{array}$ & $\begin{array}{l}0.012 * * * \\
(0.003)\end{array}$ & $\begin{array}{l}0.013 * * * \\
(0.003)\end{array}$ \\
\hline Budget balance & $\begin{array}{l}0.495 * * * \\
(0.146)\end{array}$ & $\begin{array}{l}0.496 * * * \\
(0.147)\end{array}$ & $\begin{array}{l}0.518 * * * \\
(0.146)\end{array}$ & $\begin{array}{l}0.222 * * \\
(0.083)\end{array}$ & $\begin{array}{l}0.237 * * * \\
(0.085)\end{array}$ \\
\hline Old dependency ratio & $\begin{array}{l}-0.194 * * * \\
(0.070)\end{array}$ & $\begin{array}{l}-0.193 * * * \\
(0.071)\end{array}$ & $\begin{array}{l}-0.203 * * * \\
(0.067)\end{array}$ & $\begin{array}{l}-0.171 * * \\
(0.071)\end{array}$ & $\begin{array}{l}-0.171 * * \\
(0.067)\end{array}$ \\
\hline Democratic accountability & $\begin{array}{l}-0.018 * * * \\
(0.004)\end{array}$ & $\begin{array}{l}-0.018 * * * \\
(0.004)\end{array}$ & $\begin{array}{l}-0.018 * * * \\
(0.005)\end{array}$ & $\begin{array}{l}-0.010 * * * \\
(0.003)\end{array}$ & $\begin{array}{l}-0.010 * * * \\
(0.003)\end{array}$ \\
\hline Lagged NFA & & & & $\begin{array}{l}0.045^{* * * *} \\
(0.011)\end{array}$ & $\begin{array}{l}0.046 * * * \\
(0.010)\end{array}$ \\
\hline Constant & $\begin{array}{l}0.075 * * * \\
(0.020)\end{array}$ & $\begin{array}{l}0.073 * * * \\
(0.022)\end{array}$ & $\begin{array}{l}0.067 * * * \\
(0.024)\end{array}$ & $\begin{array}{l}0.042 * * \\
(0.016)\end{array}$ & $\begin{array}{l}0.035^{*} \\
(0.018)\end{array}$ \\
\hline Time effects & & & & Yes & Yes \\
\hline $\mathrm{R}^{2}$ & 0.756 & 0.757 & 0.753 & 0.590 & 0.587 \\
\hline Observations & 46 & 46 & 46 & 935 & 935 \\
\hline Regression type & $\begin{array}{l}\text { Cross- } \\
\text { sectional }\end{array}$ & $\begin{array}{l}\text { Cross- } \\
\text { sectional }\end{array}$ & $\begin{array}{l}\text { Cross- } \\
\text { sectional }\end{array}$ & Panel & Panel \\
\hline
\end{tabular}

Notes: The dependent variable in models (1)-(3) is the long-run current account balance (ratio to GDP). Heteroscedasticity robust standard errors are in parentheses. The dependent variable in models (4)-(5) is the current account balance (ratio to GDP). Panel robust standard errors are in parentheses (clustering on the panel variable). *, ** and *** denote statistical significance at the $10 \%, 5 \%$ and $1 \%$ levels. Fragmented firm-level wage coordination is the reference category for the coordination of wage bargaining in models (1), (2) and (4). The reference category includes 11 countries (models (1)-(2)) or 195 observations (model (4)).

Our models in Table 2 predict that the current account surplus (deficit) of a country with a high degree of coordination of wage bargaining is $2.5 \%$ of GDP larger (smaller) than for a country with no coordination of wage bargaining. This is a rather

\footnotetext{
${ }^{13}$ See the country coverage and sample period in Table A2 in the Appendix.
} 
substantial effect, and comparable with the effects of other institutional factors reported in previous studies (e.g., Gruber and Kamin, 2007, Figure 2). The apparent channel here is via wage moderation. Thus, in Table 3 we estimate the following equation using the OLS estimator:

$\Delta N U L C_{i}=\alpha+\operatorname{Coord}_{i}+G D P_{i}+\varepsilon_{i}$,

where $\Delta \mathrm{NULC}_{\mathrm{i}}$ is change in nominal unit labor costs in country $\mathrm{i}, \alpha$ is an intercept, GDP $_{\mathrm{i}}$ is GDP per capita in country $\mathrm{i}$ and $\varepsilon_{\mathrm{i}}$ is a residual. ${ }^{14}$ Table 3 presents the results from estimating equation (7). The relation between the coordination of wage bargaining and change in nominal unit labor costs seems to be sensitive to whether or not Bulgaria and Romania are included (see also Figures A2-A3 in the Appendix) and whether or not we control GDP per capita. If we include the change in nominal unit labor costs as an additional control to models (1)-(5), the results for the relation between the degree of coordination of wage bargaining and current account balances do not change (see Table $\mathrm{S} 3$ in the Electronic supplementary material). This implies that our result is not entirely driven by wage moderation.

\footnotetext{
${ }^{14}$ Due to the limited country coverage of the AMECO database, the number of countries decreases from 46 to 36. See, e.g., Fischer et al. (2018) for a comparison of various indicators of international price competitiveness.
} 
Table 3. Coordination of wage bargaining and nominal unit labor costs

\begin{tabular}{|c|c|c|c|c|}
\hline Variable & (6) & (7) & (8) & (9) \\
\hline $\begin{array}{l}\text { Coordination of wage bargaining } \\
(1=\text { Firm-level, } \ldots, 5=\text { Centralized })\end{array}$ & $\begin{array}{l}-0.009 * \\
(0.005)\end{array}$ & $\begin{array}{l}0.000 \\
(0.004)\end{array}$ & $\begin{array}{l}-0.009 * * * \\
(0.003)\end{array}$ & $\begin{array}{l}-0.004 \\
(0.003)\end{array}$ \\
\hline GDP per capita & & $\begin{array}{l}-0.017 * * \\
(0.006)\end{array}$ & & $\begin{array}{l}-0.008 * * * \\
0.003\end{array}$ \\
\hline Constant & $\begin{array}{l}0.071 * * * \\
(0.016)\end{array}$ & $\begin{array}{l}0.093 * * * \\
(0.019)\end{array}$ & $\begin{array}{l}0.062 * * * \\
(0.009)\end{array}$ & $\begin{array}{l}0.073 * * * \\
(0.009)\end{array}$ \\
\hline $\mathrm{R}^{2}$ & 0.058 & 0.319 & 0.238 & 0.453 \\
\hline Number of countries & 36 & 36 & 34 & 34 \\
\hline
\end{tabular}

\subsection{Coordination of wage bargaining and speed of current account adjustment}

\subsubsection{Two-step procedure}

Table 4 presents the results from estimating equation (4). Compared to our reference category no coordination in wage bargaining (fragmented firm-level wage bargaining), a high degree of coordination in wage bargaining (centralized wage bargaining) decreases the speed of adjustment of the current account toward its long-run equilibrium. Due to the central role of the US dollar in the world economy, the US has enjoyed an exorbitant privilege that relaxes its external constraint (Gourinchas and Rey, 2007, 2014; Prasad, 2014; Chinn, 2015). When we include a dummy variable for the US in model (11), the result becomes even stronger. ${ }^{15}$ In model (12), we make a distinction between the two subcategories of centralized wage bargaining. In model (13), we include coordination of wage bargaining as a continuous variable. This identification assumes

\footnotetext{
${ }^{15}$ The financial openness index, GDP per capita, trade openness and real GDP per capita growth were excluded from the main tables because they were statistically insignificant in all models (see Tables S4, S7-S9 in the Electronic supplementary material). This finding comports with previous studies (Ju et al. 2014, Tables 3-4; Chinn and Wei 2013, Tables 5-11; Ghosh et al. 2013, Table 3). Table S5 in the Electronic supplementary material presents results when a dummy variable for the EMU-12 countries is included as a control variable. EMU membership decreases the speed of current account adjustment, but the result for the relationship between the speed of current account adjustment and degree of coordination of wage bargaining remains unchanged.
} 
that the successive categories of the degree of coordination of wage bargaining are equally spaced.

According to the two-step procedure, the speed of adjustment of the current account toward its long-run equilibrium decreases monotonically with the degree of coordination of wage bargaining. The result is not driven by an outlier (see Figure A4 in the Appendix) and it is insensitive to whether we treat the coordination of wage bargaining as continuous or not. ${ }^{16}$

This finding seems theoretically plausible as the aggregate shocks in the exporting sector are largely driven by idiosyncratic shocks and the presence of idiosyncratic shocks increases the importance of labor market flexibility. It is also consistent with the theory on collective bargaining and wage dispersion and with microlevel evidence on wages as firm-level wage bargaining increases the responsiveness of wages to firmspecific profitability (e.g., Barth and Zweimüller 1995; Guertzgen 2009; Garloff and Guertzgen 2012). If we split the sample according to the IMF's country classification and compare the two subsamples, we find that the negative relationship between the coordination of wage bargaining and speed of current account adjustment is equally strong for advanced economies and emerging market and developing economies (see Figures S3-S4 and Table S6 in the Electronic supplementary material). ${ }^{17}$ However, if we compare the goodness-of-fit (i.e., R2) of the models in Table 4 to that of the models in Table 2, it is evident that we are not as successful in explaining cross-country

\footnotetext{
${ }^{16}$ In an earlier version of this paper, we tested whether the length of collective wage agreements affects the speed of current account adjustment. It initially seemed that there would be a negative relationship between the two (longer collective wage agreements would make the current account adjustment slower), but it turned out that this result was driven by only one country - India. If India is excluded, the coefficient of the length of collective wage agreements is not statistically significant even at the $30 \%$ level.

${ }^{17}$ We tested a dummy variable for the advanced economies for the regression models presented in Table 4 and found it to be statistically insignificant.
} 
differences in the rate of current account adjustment as cross-country differences in current account balances.

Table 4. Coordination of wage bargaining and speed of current account adjustment ${ }^{18}$

\begin{tabular}{|c|c|c|c|c|}
\hline Variable & (10) & (11) & (12) & (13) \\
\hline \multicolumn{5}{|l|}{ Coordination of wage bargaining: } \\
\hline Industry and firm-level & $\begin{array}{l}0.023 \\
(0.066)\end{array}$ & $\begin{array}{l}0.051 \\
(0.063)\end{array}$ & $\begin{array}{l}0.058 \\
(0.062)\end{array}$ & \\
\hline Informal centralization & $\begin{array}{l}0.042 \\
(0.084)\end{array}$ & $\begin{array}{l}0.069 \\
(0.082)\end{array}$ & $\begin{array}{l}0.069 \\
(0.084)\end{array}$ & \\
\hline Centralized bargaining: & $\begin{array}{l}0.171 * * * \\
(0.059)\end{array}$ & $\begin{array}{l}0.199 * * * \\
(0.056)\end{array}$ & & \\
\hline $\begin{array}{l}\text { Centralized without } \\
\text { peace obligation }\end{array}$ & & & $\begin{array}{l}0.204 * * * \\
(0.071)\end{array}$ & \\
\hline $\begin{array}{l}\text { Centralized with } \\
\text { peace obligation }\end{array}$ & & & $\begin{array}{l}0.194 * * * \\
(0.049)\end{array}$ & \\
\hline $\begin{array}{l}\text { Coordination of wage bargaining ( } 1=\text { Firm- } \\
\text { level, } \ldots, 5=\text { Centralized) }\end{array}$ & & & & $\begin{array}{l}0.056 * * * \\
(0.015)\end{array}$ \\
\hline Constant & $\begin{array}{l}-0.359 * * * \\
(0.048)\end{array}$ & $\begin{array}{l}-0.386 * * * \\
(0.043)\end{array}$ & $\begin{array}{l}-0.386 * * * \\
(0.044)\end{array}$ & $\begin{array}{l}-0.445 * * * \\
(0.046)\end{array}$ \\
\hline US dummy variable & & $\begin{array}{l}0.302 * * * \\
(0.043)\end{array}$ & $\begin{array}{l}0.302 * * * \\
(0.044)\end{array}$ & $\begin{array}{l}0.304 * * * \\
(0.034)\end{array}$ \\
\hline $\mathrm{R}^{2}$ & 0.181 & 0.245 & 0.236 & 0.214 \\
\hline Number of countries & 46 & 46 & 46 & 46 \\
\hline
\end{tabular}

Notes: The dependent variable is a country-specific regression coefficient for an AR process with lags that characterizes the speed of adjustment of the current account toward its long-run equilibrium, i.e. $\beta_{1, \mathrm{i}}$ in equation (3). Heteroscedasticity robust standard errors are in parentheses. $* * *$ and $* * *$ denote statistical significance at the $10 \%, 5 \%$ and $1 \%$ levels. Fragmented firm-level wage coordination is the reference category for the coordination of wage bargaining in models (10)-(12). The reference category includes 11 countries.

\subsubsection{One-step procedure}

Table 5 presents the results from estimating equation (5) for each category of wage bargaining coordination. Countries with a high degree of coordination of wage bargaining experience slower current account reversion than countries with no wage bargaining coordination. The half-life of current account balance deviations is 8.1 years under centralized wage bargaining compared to 2.1 years under firm-level wage

\footnotetext{
${ }^{18}$ See the country coverage and sample period in Table A3 in the Appendix.
} 
bargaining. The difference between the extreme opposite categories is statistically significant at the $5 \%$ level (see Figure A5 in the Appendix). ${ }^{19}$

Table 5. Coordination of wage bargaining and the rate of current account reversion

\begin{tabular}{lllll}
\hline & $(14)$ & $(15)$ & $(16)$ & $(17)$ \\
Variable & Centralized & $\begin{array}{l}\text { Coordination of wage bargaining: } \\
\text { Informal } \\
\text { centralization }\end{array}$ & $\begin{array}{l}\text { Industry and } \\
\text { firm-level }\end{array}$ & $\begin{array}{l}\text { Fragmented } \\
\text { firm-level }\end{array}$ \\
\hline $\mathrm{CA}_{\mathrm{t}-1}$ & $\begin{array}{l}0.904 * * * \\
(0.029)\end{array}$ & $\begin{array}{l}0.932^{* * *} \\
(0.020)\end{array}$ & $\begin{array}{l}0.751^{* * *} \\
(0.040)\end{array}$ & $\begin{array}{l}0.719^{* * * *} \\
\mathrm{R}^{2}\end{array}$ \\
0.813 & 0.826 & 0.595 & 0.522 \\
Observations & 457 & 274 & 328 & 285 \\
\hline
\end{tabular}

In addition all regressions include a constant.

Notes: The dependent variable is current account balance (ratio to GDP). $\mathrm{CA}_{\mathrm{t}-1}$ is the lagged term of current account balance. Panel robust standard errors are in parentheses (clustering on the panel variable). *,** and $* * *$ denote statistical significance at the $10 \%, 5 \%$ and $1 \%$ levels.

Table 6 presents the results from estimating equation (6). Both approaches of the one-step procedure give similar results. In model (19), the relationship between the degree of coordination of wage bargaining and rate of current account reversion is monotonic and countries with a high degree of coordination of wage bargaining experience slower current account reversion. ${ }^{20}$ Thus, the one-step procedure confirms the finding of the two-step procedure.

\footnotetext{
${ }^{19}$ Table S7 in the Electronic supplementary material presents results with financial openness index included as a control variable.

${ }^{20}$ Table S8 in the Electronic supplementary material presents results when the financial openness index is included as a control variable. We tested a dummy variable for the advanced economies for the regression models presented in Table 6 and found it to be statistically insignificant.
} 
Table 6. Coordination of wage bargaining and rate of current account reversion

\begin{tabular}{|c|c|c|}
\hline Variable & (18) & (19) \\
\hline $\mathrm{CA}_{\mathrm{t}-1}$ & $\begin{array}{l}0.719 * * * \\
(0.024)\end{array}$ & $\begin{array}{l}0.680 * * * \\
(0.053)\end{array}$ \\
\hline $\mathrm{CA}_{\mathrm{t}-1} \mathrm{x}$ Industry and firm-level bargaining & $\begin{array}{l}0.031 \\
(0.051)\end{array}$ & \\
\hline $\mathrm{CA}_{\mathrm{t}-1} \mathrm{x}$ Informal centralization & $\begin{array}{l}0.213 * * * \\
(0.030)\end{array}$ & \\
\hline $\mathrm{CA}_{\mathrm{t}-1} \times$ Centralized bargaining & $\begin{array}{l}0.185 * * * \\
(0.038)\end{array}$ & \\
\hline $\mathrm{CA}_{\mathrm{t}-1} \mathrm{x}$ Coordination of wage bargaining & & $\begin{array}{l}0.065 * * * \\
(0.015)\end{array}$ \\
\hline \multicolumn{3}{|l|}{ Coordination of wage bargaining: } \\
\hline Industry and firm-level & $\begin{array}{l}-0.000 \\
(0.003)\end{array}$ & \\
\hline Informal centralization & $\begin{array}{l}0.009 * * * \\
(0.003)\end{array}$ & \\
\hline Centralized bargaining & $\begin{array}{l}0.010 * * * \\
(0.002)\end{array}$ & \\
\hline $\begin{array}{l}\text { Coordination of wage bargaining } \\
\text { (1=Firm-level, .., } 4=\text { Centralized })\end{array}$ & & $\begin{array}{l}0.003 * * * \\
(0.001)\end{array}$ \\
\hline Constant & $\begin{array}{l}-0.008 * * * \\
(0.002)\end{array}$ & $\begin{array}{l}-0.011 * * * \\
(0.003)\end{array}$ \\
\hline $\mathrm{R}^{2}$ & 0.779 & 0.776 \\
\hline Observations & 1344 & 1344 \\
\hline
\end{tabular}

Notes: The dependent variable is current account balance (ratio to GDP). Panel robust standard errors are in parentheses (clustering on the panel variable). ${ }^{*}, * *$ and $* * *$ denote statistical significance at the $10 \%, 5 \%$ and $1 \%$ levels. Fragmented firm-level wage coordination is the reference category for the coordination of wage bargaining in model (18). The reference category includes 285 observations.

\subsubsection{Asymmetric effects}

As the degree of coordination of wage bargaining affects the current account balance in the long run and the speed of adjustment of the current account toward its long-run equilibrium, it is important to consider whether current account reversion rates depend the running of a surplus or deficit. Following Chinn and Wei (2013), we test the asymmetric effects by estimating the following equation using the OLS estimator:

$C A_{i t}=\rho_{0}+\rho_{1} C A_{i t-1}+\rho_{2} C A_{i t-1} \operatorname{pos} C A_{i t-1}+\varepsilon_{i t}$, 
where $\mathrm{CA}_{\mathrm{it}}$ is the current account balance (ratio to GDP) of country $\mathrm{i}$ in period $t, \rho_{0}$ is an intercept, posCA $\mathrm{A}_{\mathrm{it}-1}$ is a dummy variable that equals one if $\mathrm{CA}_{\mathrm{it}-1}$ is positive and $\varepsilon_{\mathrm{it}}$ is a residual. In this identification, the coefficient $\rho_{1}$ represents the rate of reversion when the current account is negative, and the sum of two coefficients $\rho_{1}+\rho_{2}$ is the rate of reversion when the current account is positive.

Table 7 presents the results from estimating equation (8). In most categories, current account deficits are associated with higher speeds of current account adjustment. However, the difference is not statistically significant and the positive association between the degree of coordination of wage bargaining and the current account balance (section 3.1) does not explain why the speed of adjustment of the current account toward its long-run equilibrium decreases monotonically with the degree of coordination of wage bargaining. Irrespective of whether current account is positive or negative, centralized wage bargaining is associated with slower current account reversion than fragmented firm-level wage bargaining.

Table 7. Coordination of wage bargaining and asymmetric speed of current account adjustment

\begin{tabular}{|c|c|c|c|c|}
\hline \multirow[b]{3}{*}{ Variable } & (20) & $(21)$ & (22) & (23) \\
\hline & \multicolumn{4}{|c|}{ Coordination of wage bargaining: } \\
\hline & Centralized & $\begin{array}{l}\text { Informal } \\
\text { centralization }\end{array}$ & $\begin{array}{l}\text { Industry and } \\
\text { firm-level }\end{array}$ & $\begin{array}{l}\text { Fragmented } \\
\text { firm-level }\end{array}$ \\
\hline $\mathrm{CA}_{\mathrm{t}-1}$ & $\begin{array}{l}0.859 * * * \\
(0.053)\end{array}$ & $\begin{array}{l}0.853 * * * \\
(0.087)\end{array}$ & $\begin{array}{l}0.735 * * * \\
(0.039)\end{array}$ & $\begin{array}{l}0.750 * * * \\
(0.029)\end{array}$ \\
\hline $\mathrm{CA}_{\mathrm{t}-1} \times \operatorname{pos} \mathrm{A}_{\mathrm{t}-1}$ & $\begin{array}{l}0.094 \\
(0.070)\end{array}$ & $\begin{array}{l}0.103 \\
(0.101)\end{array}$ & $\begin{array}{l}0.152 \\
(0.100)\end{array}$ & $\begin{array}{l}-0.197 * \\
(0.106)\end{array}$ \\
\hline $\mathrm{R}^{2}$ & 0.814 & 0.827 & 0.592 & 0.524 \\
\hline Observations & 457 & 274 & 328 & 285 \\
\hline
\end{tabular}

In addition all regressions include a constant.

Notes: The dependent variable is current account balance (ratio to GDP). $\mathrm{CA}_{\mathrm{t}-1}$ is the lagged term of current account balance. posCA $\mathrm{A}_{\mathrm{t}-1}$ is a dummy variable which equals one, if $\mathrm{CA}_{\mathrm{it}-1}$ is positive. Panel robust standard errors are in parentheses (clustering on the panel variable). *,** and *** denote statistical significance at the $10 \%, 5 \%$ and $1 \%$ levels. 


\subsubsection{Wage bargaining, exchange rate stability and current account}

As the literature on the rate of reversion of the current account concentrates on examining the role of exchange rate regimes, we analyze the interaction effect of wagebargaining coordination and exchange rate stability on the speed of current account adjustment. We measure exchange rate stability with the continuous exchange rate stability index proposed by Aizenman, Chinn and Ito (2010) rather than usual dichotomous de facto exchange rate regime classifications. We estimate the following equation by the OLS estimator:

$\beta_{1, i}=\alpha+\gamma_{1 j} \sum_{j=1}^{k} \operatorname{Coord}_{j i}+\gamma_{2 j}\left(E R S_{i} \sum_{j=1}^{k} \operatorname{Coord}_{j i}\right)+\gamma_{3} E R S_{i}+\varepsilon_{i}$,

where $\beta_{1, \mathrm{i}}$ is the speed of adjustment of the current account toward its long-run equilibrium (i.e. $\beta_{1, \mathrm{i}}$ in equation (3)) in country $\mathrm{i}, \alpha$ is an intercept, $\operatorname{Coord}_{\mathrm{ji}}$ is a binary dummy variable for the coordination of wage bargaining of country $i$ in regime $j, E S_{i}$ measures exchange rate stability in country $i$ and $\varepsilon_{\mathrm{i}}$ is a residual. ${ }^{21}$

Table 8 presents the results from estimating equation (9). Model (24) shows that, while exchange rate stability decreases the speed of current account adjustment, there is a strong negative interaction between the effects of coordination of wage bargaining and exchange rate stability on the speed of current account adjustment. This result is

\footnotetext{
${ }^{21}$ The exchange rate stability index does not cover the US. Compared to Table 4 , the number of countries decreases from 46 to 45 in Table 8 . We use the mean value of the exchange rate stability index of the sample period for the exchange rate stability. The values of exchange rate stability vary between 0.245 and 0.837 .
} 
insensitive to whether we treat the coordination of wage bargaining as continuous (model (25)) or not. $^{22}$

Table 8. Coordination of wage bargaining, exchange rate stability and speed of current account adjustment

\begin{tabular}{lll}
\hline Variable & $(24)$ & $(25)$ \\
\hline Coordination of wage bargaining: & & \\
Industry and firm-level & 0.060 \\
& $(0.193)$ \\
Informal centralization & $0.531^{* * *}$ \\
& $(0.168)$ \\
Centralized bargaining: & $0.515^{* * *}$ \\
& $(0.164)$ & \\
Coordination of wage bargaining & & $0.161^{* * *}$ \\
(1=Firm-level,.., 4=Centralized) & & $(0.049)$
\end{tabular}

Interaction between Coordination of wage bargaining and Exchange rate stability:
Industry and firm-level wage bargaining $\mathrm{x}$
$-0.083$
Exchange rate stability
(0.370)
Informal centralization $\mathrm{x}$
$-1.016^{* * *}$
Exchange rate stability
(0.366)
Centralized wage bargaining $\mathrm{x}$
$-0.689 * *$
Exchange rate stability
(0.314)

Coordination of wage bargaining $\mathrm{x}$

$-0.207 *$

Exchange rate stability

Exchange rate stability

Constant

$-0.621 * * *$

$-0.796 * * *$

Constant

(0.144)

$\mathrm{R}^{2}$

0.318

0.262

Number of countries

45

45

Notes: The dependent variable is a country-specific regression coefficient for an AR process with lags that characterizes the speed of adjustment of the current account toward its long-run equilibrium, i.e. $\beta 1, i$ in equation (3). Heteroscedasticity robust standard errors are in parentheses. *, ** and *** denote statistical significance at the $10 \%, 5 \%$ and $1 \%$ levels. Fragmented firm-level wage coordination is the reference category for the coordination of wage bargaining in model (24). The reference category includes 10 countries.

${ }^{22}$ Table S9 in the Electronic supplementary material presents the results when financial openness index and GDP per capita are included as control variables. Table S10 in the Electronic supplementary material presents results when a dummy variable for the EMU-12 countries is included as a control variable. 
Figure 1 portrays the marginal effects of the explanatory variables on the speed of current account adjustment. When exchange rate stability is low, the degree of coordination of wage bargaining has a large negative effect on the speed of current account adjustment. As exchange rate stability increases, the effect of wage bargaining coordination on current account adjustment diminishes. Similarly, if the degree of coordination of wage bargaining is low, the degree of exchange rate stability has a large negative effect on the speed of current account adjustment. As the degree of coordination of wage bargaining increases, the effect of exchange rate stability on current account adjustment diminishes.

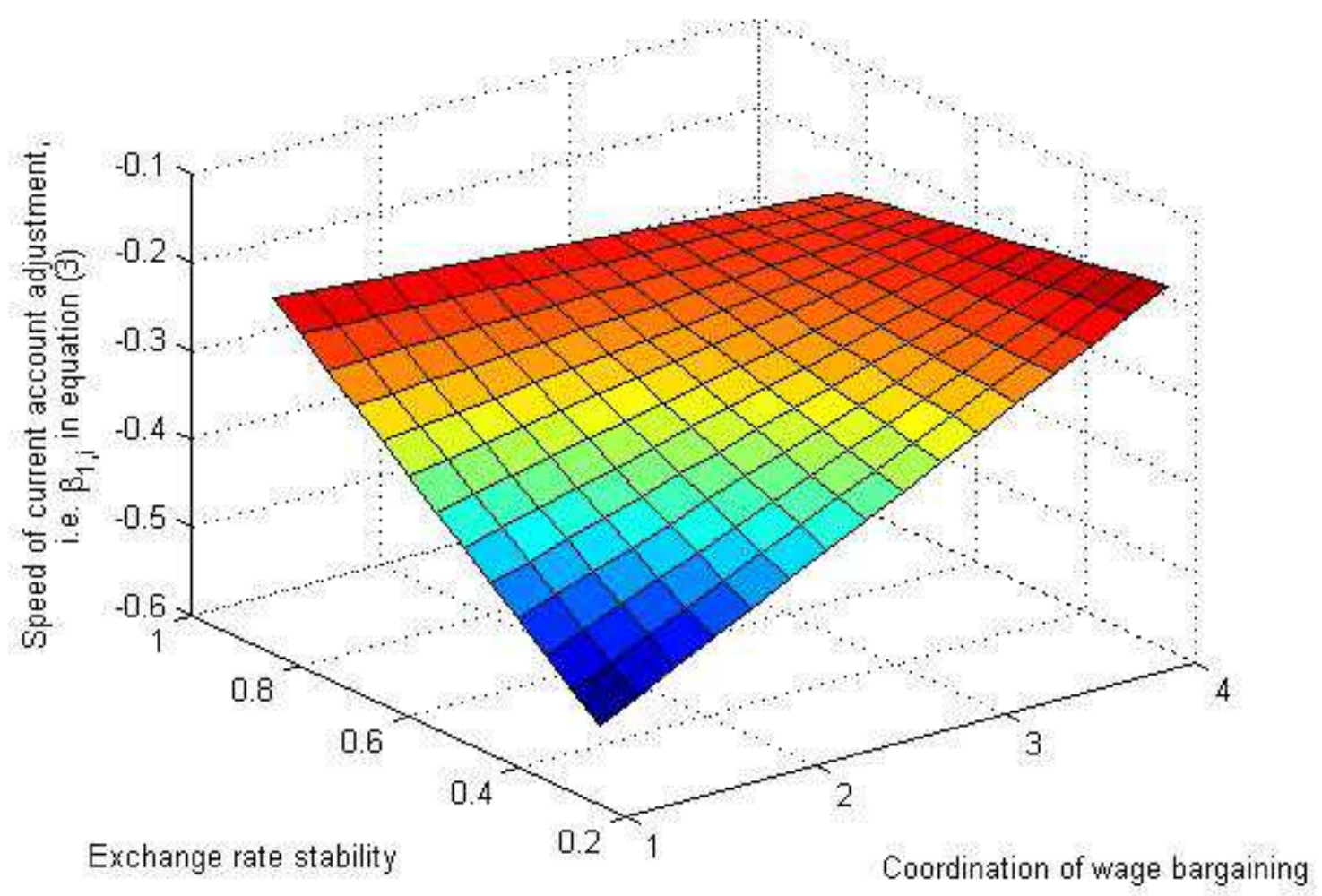

Figure 1. Interaction effect of coordination of wage bargaining and exchange rate stability on the speed of current account adjustment. Model (25).

A negative interaction term between coordination of wage bargaining and exchange rate stability suggests 1) that the level of wage bargaining should be adjusted 
for the prevailing exchange rate regime to obtain the desired speed of current account adjustment, and 2) that firm-level wage flexibility and economy-wide exchange rate flexibility are not substitutes for shock absorption.

We are unaware of any theoretical model that would explicitly analyze the interaction effect of these two adjustment channels on the speed of current account adjustment. ${ }^{23}$ Intuitively, it appears reasonable that exchange rate adjustment is sufficient if all shocks are aggregate shocks. On the other hand, if all shocks are idiosyncratic shocks, external balance is possibly obtained faster by firm-level wage adjustment than by economy-wide exchange rate adjustment. The interaction effect of wage bargaining coordination and exchange rate stability on the speed of current account adjustment deserves closer examination in future studies.

\section{Conclusions}

This paper contributes to the current account literature by testing the impact of labor market institutions on current account dynamics. We provide empirical evidence that the degree of coordination of wage bargaining affects both the current account balance and speed of adjustment of the current account toward its long-run equilibrium.

Our estimates suggest that a high degree of coordination of wage bargaining has a positive effect on the current account balance over the long run and a negative effect on the speed of current account adjustment. Compared to a country with no coordination of wage bargaining, a country with a high degree of coordination of wage bargaining tends to run larger current account surpluses or smaller deficits by $2.5 \%$ of the GDP. The size

\footnotetext{
${ }^{23}$ Rhee and Song (2017) examine the impact of changes in the degree of real wage flexibility on the economy's equilibrium properties under different exchange rate regimes.
} 
of this effect is comparable with effects of other institutional factors noted in previous studies. Moreover, this result is not driven by the wage moderation induced by centralized coordination. It is possible that the variable measuring the degree of coordination of wage bargaining is also a proxy for export promotion policies.

Japan, China and Germany - the three most recent current account surplus world champions - all have a high degree of coordination of wage bargaining. The positive relationship between the coordination of wage bargaining and current account balance seems to be stronger among the advanced economies than emerging market and developing economies.

The half-life of current account balance deviations is 8.1 years under the centralized wage coordination, compared to 2.1 years under the firm-level wage coordination. The negative relationship between the coordination of wage bargaining and speed of current account adjustment seems to be equally strong among the advanced economies and the emerging market and developing economies. If current account balance is positive, current account reversion is slower. However, this type of asymmetry does not alter the negative association between the degree of coordination of wage bargaining and the speed of current account reversion.

We also found that coordination of wage bargaining and exchange rate stability are mutually related to the speed of current account reversion. When exchange rate stability is low, the degree of coordination of wage bargaining has a large negative effect on the speed of current account adjustment. It seems that overall the determinants of current account balances are understood better than the determinants of the rate of current account adjustment. Our findings make a contribution to both, but does not change this disparity. 
Since the adoption of the euro, EMU member countries have been unable to use exchange rate adjustment as a policy instrument. This change has increased the importance of labor market institutions in economic adjustment. In this respect, the paucity of research on the impact of labor market institutions on current account dynamics is surprising. Instead, studies on determinants of current account balances tend to concentrate on other institutional factors. The empirical literature on the rate of reversion of current account also tends to be limited to examining the role of the exchange rate regime. Our results propose a new direction for research. Hopefully, we will gather more evidence on the relation between the degree of coordination of wage bargaining and cost- competitiveness, as well as develop models with microfoundations that help us understand cross-country heterogeneity in the speed of adjustment of the current account. Finally, the interaction between coordination of wage bargaining and exchange rate regime deserves closer examination. 


\section{References}

Aidt TS, Tzannatos Z (2008) Trade unions, collective bargaining and macroeconomic performance: a review. Ind Relat J 39: 258-295.

Aizenman J, Chinn MD, Ito H (2010) The emerging global financial architecture: tracing and evaluating the new patterns of the trilemma's configurations. J Int Money Financ 29: 615-641.

Barth E, Zweimüller J (1995) Relative wages under decentralized and corporatist bargaining systems. Scand J Econ 97: 369-384.

Bernard AB, Jensen JB, Redding SJ, Schott, PK (2012) The empirics of firm heterogeneity and international trade. Annu Rev Econ 4: 283-313.

Ca' Zorzi M, Chudik A, Dieppe A (2012) Thousands of models, one story: Current account imbalances in the global economy. J Int Money Financ 31: 1319-38.

Cahuc P, Carcillo S, Zylberberg A (2014) Labor Economics, $2^{\text {nd }}$ edition. The MIT Press, Cambridge (MA).

Calmfors L, Driffill J (1988) Centralization of wage bargaining. Econ Policy 3 (6): 1361.

Canals C, Gabaix X, Vilarrubia JM, Weinstein D (2007) Trade patterns, trade balances, and idiosyncratic shocks. Banco de España Working Paper No. 0721.

Carlin W, Soskice D (2006) Macroeconomics: imperfections, institutions, and policies. Oxford University Press, Oxford (UK).

Chinn, MD (2015) Emerging market economies and the next reserve currencies. Open Econ Rev 26: 155-174.

Chinn MD, Ito H (2007) Current account balances, financial development and institutions: assaying the world "saving glut". J Int Money Financ 26: 546-569.

Chinn MD, Prasad ES (2003) Medium-term determinants of current accounts in industrial and developing countries: an empirical exploration. J Int Econ 59: 4776.

Chinn MD, Wei S-J (2013) A Faith-based initiative meets the evidence: Does a flexible exchange rate regime really facilitate current account adjustment? Rev Econ Stat 95: $168-184$.

Cuñat A, Melitz MJ (2012) Volatility, labor market flexibility, and the pattern of comparative advantage. J Eur Econ Assoc 10: 225-254.

Del Rosal I (2013) The granular hypothesis in EU country exports. Econ Lett 120: 433436.

Du Q, Liu Q (2015) Labor market flexibility and the real exchange rate. Econ Lett 136: $13-18$.

Fischer C, Hossfeld O, Radeck K (2018) On the suitability of alternative competitiveness indicators for explaining real exports of advanced economies. Open Econ Rev 29: 119-139.

Flanagan RJ (1999) Macroeconomic performance and collective bargaining: an international perspective. J Econ Lit 37: 1150-1175.

Freund C, Pierola MD (2015) Export superstars. Rev Econ Stat 97: 1023-1032.

Garloff A, Guertzgen N (2012) Collective wage contracts, opt-out clauses, and firm wage differentials: evidence from linked employer-employee data. Ind Relat 51: 731-748. 
Ghosh A, Qureshi M, Tsangarides C (2013) Is the exchange rate regime really irrelevant for external adjustment? Econ Lett 118: 104-109.

Gourinchas P-O, Rey H (2007) From world banker to world venture capitalist: US external adjustment and the exorbitant privilege. In: Clarida R (ed), G-7 Current account imbalances: sustainability and adjustment. University of Chicago Press, Chicago (IL), pp. 11-55.

Gourinchas P-O, Rey H (2014) External adjustment, global imbalances, valuation effect. In: Gopinath G, Helpman E, Rogoff K (eds.), Handbook of International Economics, Volume 4. North-Holland, pp. 585-645.

Gruber JW, Kamin SB (2007) Explaining the global pattern of current account imbalances. J Int Money Financ 26: 500-522.

Guertzgen N (2009) Rent-sharing and collective bargaining coverage: evidence from linked employer-employee data. Scan J Econ 111: 323-349.

Ju J, Shi K, Wei S-J (2014) On the connections between intra-temporal and intertemporal trades. J Int Econ 92: S36-S51.

Prasad ES (2014) The dollar trap. Princeton University Press, Princeton (NJ).

Rhee HJ, Song J (2017) Real wage flexibility, economic fluctuations, and exchange rate regimes. Open Econ Rev 28: 633-659.

Syversen C (2011) What determines productivity? J Econ Lit 49: 326-365.

Traxler F, Brandl B (2012) Collective bargaining, inter-sectoral heterogeneity and competitiveness: a cross-national comparison of macroeconomic performance. Brit J Ind Relat 50: 73-98.

Visser J (2013) Wage bargaining institutions - from crisis to crisis. European Economy. Economic Papers 488. 


\section{Appendix}

Table A1. Data description

\begin{tabular}{|c|c|c|}
\hline Variable & Description & Source $^{\mathrm{a}}$ \\
\hline Current account balance & Current account balance (ratio to GDP). & WDI; WEO \\
\hline $\begin{array}{l}\text { Coordination of wage } \\
\text { bargaining }\end{array}$ & $\begin{array}{l}\text { Mode of coordination of wage-setting during sample } \\
\text { period. } 1 \text { = fragmented firm-level wage bargaining, } 2= \\
\text { mixed industry and firm-level bargaining, } 3=\text { informal } \\
\text { centralization, } 4 \text { = centralized bargaining without peace } \\
\text { obligation, } 5=\text { centralized bargaining with peace } \\
\text { obligation. }\end{array}$ & ICTWSS \\
\hline GDP per capita & $\begin{array}{l}\text { GDP per capita, constant } 2010 \text { US dollars (in tens of } \\
\text { thousands of US dollars) }\end{array}$ & WDI \\
\hline Budget balance & Government budget balance (ratio to GDP) & $\begin{array}{l}\text { WDI, WEO, IFS, GFS, } \\
\text { OECD, Eurostat, IFS } \\
\text { yearbook, AFDB, AMF, } \\
\text { EBRD }\end{array}$ \\
\hline Dependency ratios & $\begin{array}{l}\text { Old (Child) dependency ratio: Number of people aged } \\
65 \text { or more (aged 0-14) divided by the number of people } \\
\text { aged } 15-64\end{array}$ & WDI \\
\hline Democratic accountability & $\begin{array}{l}\text { International Country Risk Guide: Democratic } \\
\text { Accountability. Scaled between } 1 \text { and } 6 .\end{array}$ & PRS \\
\hline NFA & Net foreign asset position (ratio to GDP) & EWNII \\
\hline Financial openness & $\begin{array}{l}\text { Mean of the Chinn-Ito index during the sample period. } \\
\text { The index measures financial account openness. Scaled } \\
\text { between }-1.87 \text { and } 2.44 \text {. }\end{array}$ & CI \\
\hline $\begin{array}{l}\text { Change in nominal unit } \\
\text { labor costs }\end{array}$ & Change in nominal unit labour costs: total economy & AMECO \\
\hline Trade openness & The sum of exports and imports (ratio to GDP) & WDI \\
\hline $\begin{array}{l}\text { GDP per capita } \\
\text { growth }\end{array}$ & Annual growth rate of real GDP per capita & WDI \\
\hline Exchange rate stability & $\begin{array}{l}\text { Mean of the exchange rate stability index during the } \\
\text { sample period. The index is normalized between } 0 \text { and } \\
\text { 1. Larger values imply more stable exchange rate. }\end{array}$ & AIC \\
\hline $\begin{array}{l}\text { GDP per capita in the year } \\
2000\end{array}$ & $\begin{array}{l}\text { GDP per capita in the year } 2000 \text { (in tens of thousands of } \\
\text { US dollars) }\end{array}$ & WDI \\
\hline
\end{tabular}

a AFDB: African Development Bank Group; AIC: The Trilemma indexes by Aizenman, Chinn and Ito; AMECO: Annual macro-economic database of the European Commission's Directorate General for Economic and Financial Affairs; AMF: Arab Monetary Fund; CI: Chinn and Ito; Eurostat; EBRD: European Bank for Reconstruction and Development; EWNII: External Wealth of Nations Mark II database by Lane and MilesiFerretti; GFS: Government Finance Statistics (IMF); ICTWSS: Database on Institutional Characteristics of Trade Unions, Wage Setting, State Interventions and Social Pacts, Version 5.1; IFS: International Financial Statistics (IMF); IFS yearbook: International Financial Statistics Yearbook 1998; OECD: OECD Economic Outlook 88 database; PRS: Political Risk Services' International Country Risk Guide (Table 3B); WEO: World Economic Outlook Database, October 2015 (IMF); WDI: World Development Indicators (World Bank). 
Table A2. Coordination of wage bargaining and current account balances (46 countries, Table 2 )

\begin{tabular}{|c|c|c|c|c|c|c|c|}
\hline Country & Abbr. & $\begin{array}{l}\text { Sample } \\
\text { period in } \\
\text { cross-sections }\end{array}$ & $\begin{array}{l}\text { Sample } \\
\text { period in } \\
\text { panels }\end{array}$ & Country & Abbr. & $\begin{array}{l}\text { Sample } \\
\text { period in } \\
\text { cross-sections }\end{array}$ & $\begin{array}{l}\text { Sample } \\
\text { period in } \\
\text { panels }\end{array}$ \\
\hline Argentina & ARG & 1991-2011 & 1991-2004 & Japan & JPN & $1984-2011$ & 1984-2011 \\
\hline Australia & AUS & 1984-2011 & 1984-2011 & Korea & KOR & $1998-2011$ & 1998-2011 \\
\hline Austria & AUT & 1984-2011 & 1984-2011 & Latvia & LVA & 1993-2011 & 1999-2011 \\
\hline Brazil & BRA & 1984-2011 & 2000-2007 & Lithuania & LTU & 1994-2011 & 2000-2011 \\
\hline Bulgaria & BGR & $1992-2011$ & $1992-2011$ & Malta & MLT & 1990-2011 & 1990-2007 \\
\hline Canada & CAN & 1984-2011 & 1984-2011 & Mexico & MEX & 1994-2011 & $1995-2000$ \\
\hline Chile & CHL & 2000-2011 & 2000-2011 & Netherlands & NLD & 1984-2011 & 1984-2011 \\
\hline China & $\mathrm{CHN}$ & 2000-2011 & 2000-2011 & New Zealand & NLZ & 1984-2011 & 1984-2011 \\
\hline Croatia & HRV & 2000-2011 & 2000-2011 & Norway & NOR & 1984-2011 & 1984-2007 \\
\hline Cyprus & CYP & 1984-2011 & $1985-2011$ & Philippines & PHL & 1984-2011 & 1990 \\
\hline Czech Rep. & CZE & 1993-2011 & 1994-2011 & Poland & POL & $1990-2011$ & 1994-2011 \\
\hline Denmark & DNK & 1984-2011 & 1984-2011 & Portugal & PRT & 1984-2011 & $1995-2011$ \\
\hline Estonia & EST & $1992-2011$ & 1999-2011 & Romania & ROU & 1999-2011 & $99,01-11$ \\
\hline Finland & FIN & 1984-2011 & 1984-2011 & Singapore & SGP & 1984-2011 & 1984-2011 \\
\hline France & FRA & 1984-2011 & 1984-2011 & Slovakia & SVK & 1993-2011 & 1999-2011 \\
\hline Germany & DEU & 1984-2011 & 1984-2011 & Slovenia & SVN & $1992-2011$ & 1999-2011 \\
\hline Greece & GRC & 1984-2011 & 1984-2011 & South Africa & ZAF & 1994-2011 & 1994-2011 \\
\hline Hungary & HUN & $1990-2011$ & 1991-2011 & Spain & ESP & 1984-2011 & 1984-2011 \\
\hline India & IND & 1984-2011 & 1984-2011 & Sweden & SWE & 1984-2011 & 1984-2011 \\
\hline Indonesia & IDN & 2000-2011 & 2000-2007 & Switzerland & CHE & 1984-2011 & 1984-2011 \\
\hline Ireland & IRL & 1984-2011 & 1984-2007 & Turkey & TUR & $2002-2011$ & 2008-2011 \\
\hline Israel & ISR & 1984-2011 & 1984-2011 & UK & GBR & 1984-2011 & 1984-2011 \\
\hline Italy & ITA & 1984-2011 & 1984-2011 & US & USA & 1984-2011 & 1984-2011 \\
\hline
\end{tabular}


Table A3. Coordination of wage bargaining and speed of current account adjustment (46 countries, Table 4)

\begin{tabular}{llllll}
\hline Country & Abbr. & Sample period & Country & Abbr. & $\begin{array}{l}\text { Sample } \\
\text { period }\end{array}$ \\
& & & & & \\
\hline Argentina & ARG & $1976-2012$ & Japan & JPN & $1977-2012$ \\
Australia & AUS & $1965-2012$ & Korea & KOR & $1976-2012$ \\
Austria & AUT & $1967-2012$ & Latvia & LVA & $1992-2012$ \\
Brazil & BRA & $1975-2012$ & Lithuania & LTU & $1993-2012$ \\
Bulgaria & BGR & $1980-2012$ & Malta & MLT & $1971-2012$ \\
Canada & CAN & $1960-2012$ & Mexico & MEX & $1979-2012$ \\
Chile & CHL & $1975-2012$ & Netherlands & NLD & $1967-2012$ \\
China & CHN & $1982-2012$ & New Zealand & NLZ & $1972-2012$ \\
Croatia & HRV & $1993-2012$ & Norway & NOR & $1975-2012$ \\
Cyprus & CYP & $1980-2012$ & Philippines & PHL & $1977-2012$ \\
Czech Rep. & CZE & $1993-2012$ & Poland & POL & $1985-2012$ \\
Denmark & DNK & $1975-2012$ & Portugal & PRT & $1975-2012$ \\
Estonia & EST & $1992-2012$ & Romania & ROU & $1987-2012$ \\
Finland & FIN & $1975-2012$ & Singapore & SGP & $1972-2012$ \\
France & FRA & $1975-2012$ & Slovakia & SVK & $1993-2012$ \\
Germany & DEU & $1971-2012$ & Slovenia & SVN & $1992-2012$ \\
Greece & GRC & $1976-2012$ & South Africa & ZAF & $1960-2012$ \\
Hungary & HUN & $1982-2012$ & Spain & ESP & $1975-2012$ \\
India & IND & $1975-2012$ & Sweden & SWE & $1970-2012$ \\
Indonesia & IDN & $1981-2012$ & Switzerland & CHE & $1977-2012$ \\
Ireland & IRL & $1974-2012$ & Turkey & TUR & $1974-2012$ \\
Israel & ISR & $1965-2011$ & UK & GBR & $1970-2012$ \\
Italy & ITA & $1970-2012$ & US & $1970-2012$ \\
\hline & & & & USA &
\end{tabular}




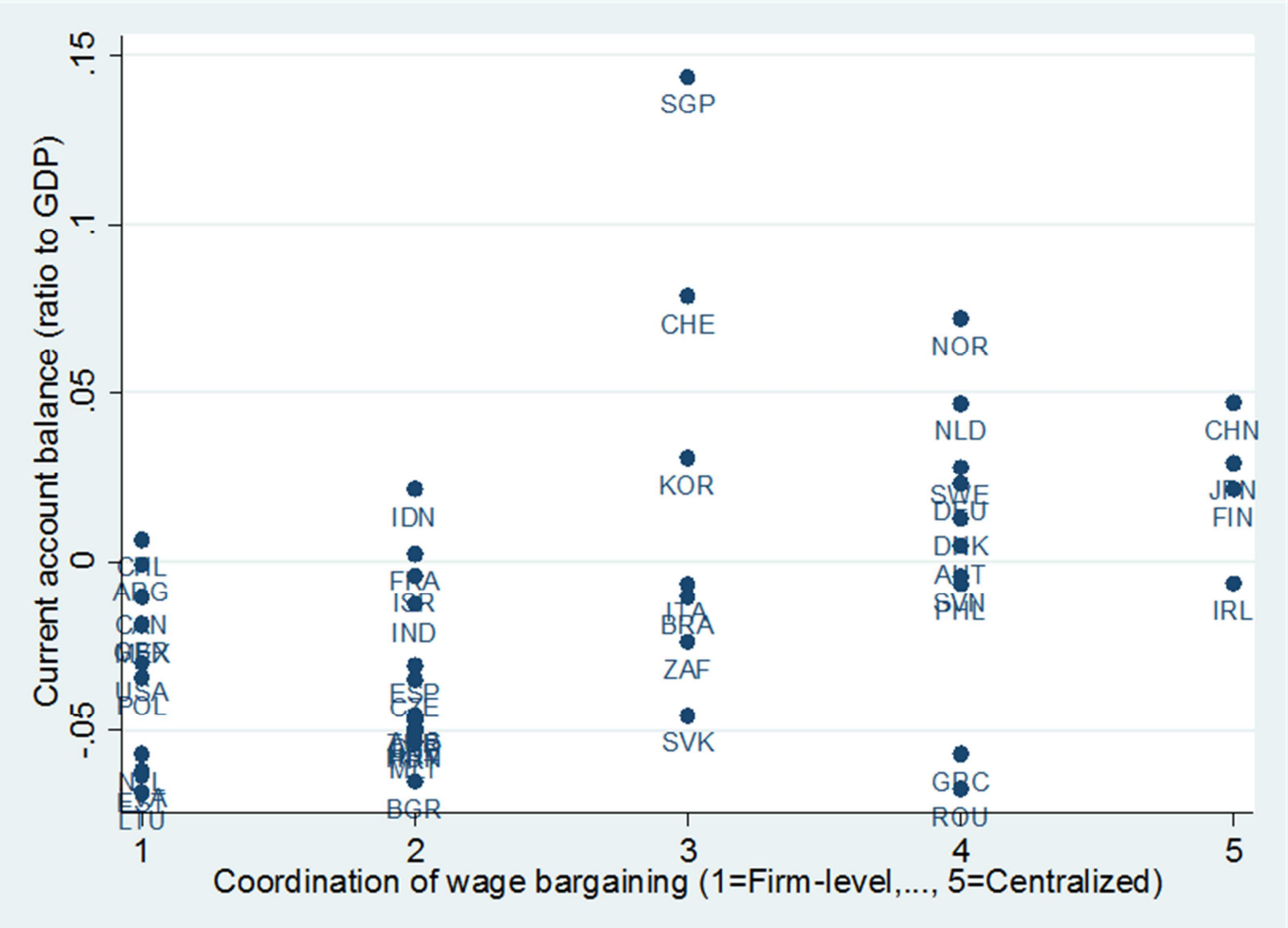

Figure A1. Coordination of wage bargaining and long-run current account balance.

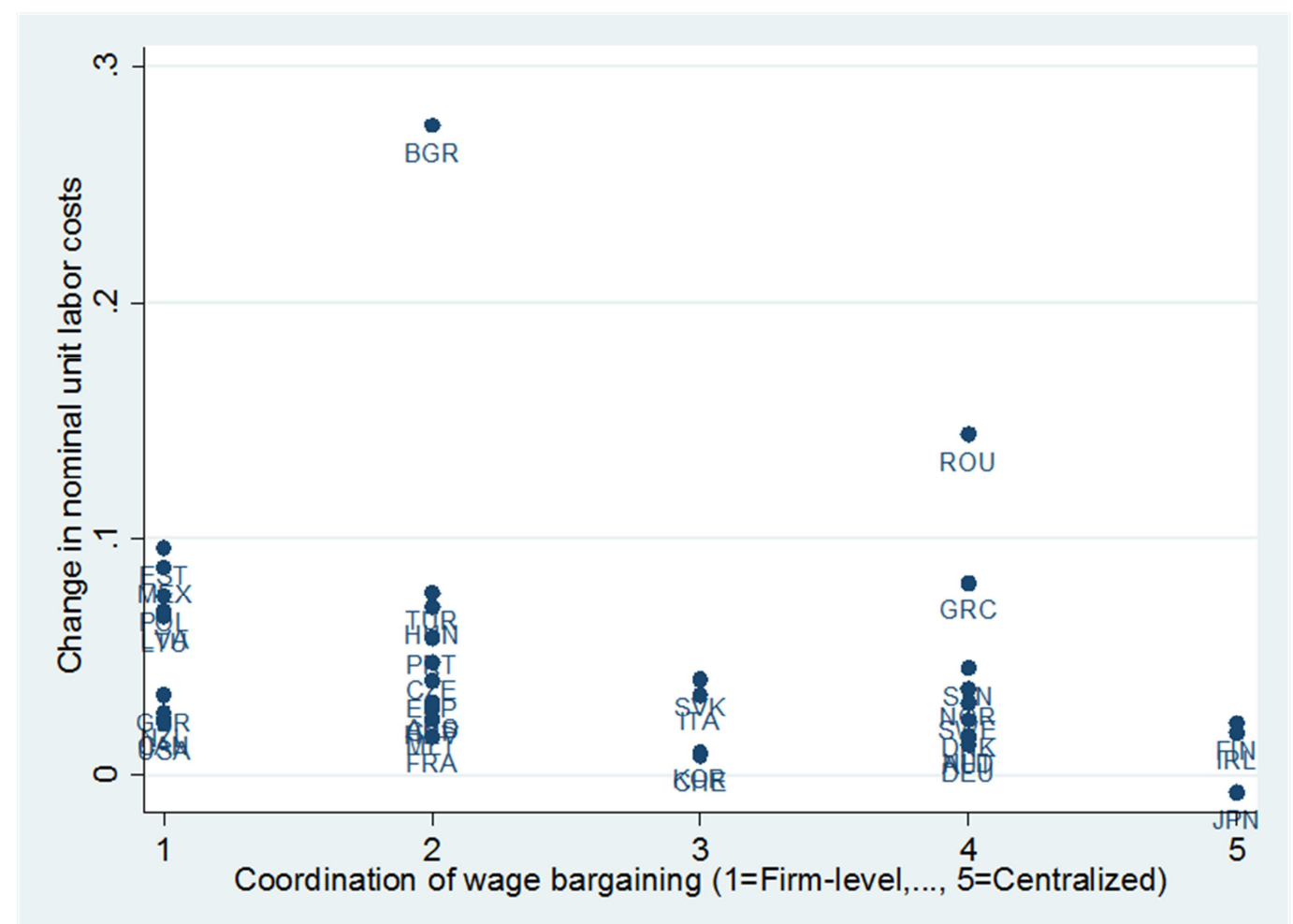

Figure A2. Coordination of wage bargaining and change in nominal unit labor costs (all 36 countries for which we have data on nominal unit labor costs). 


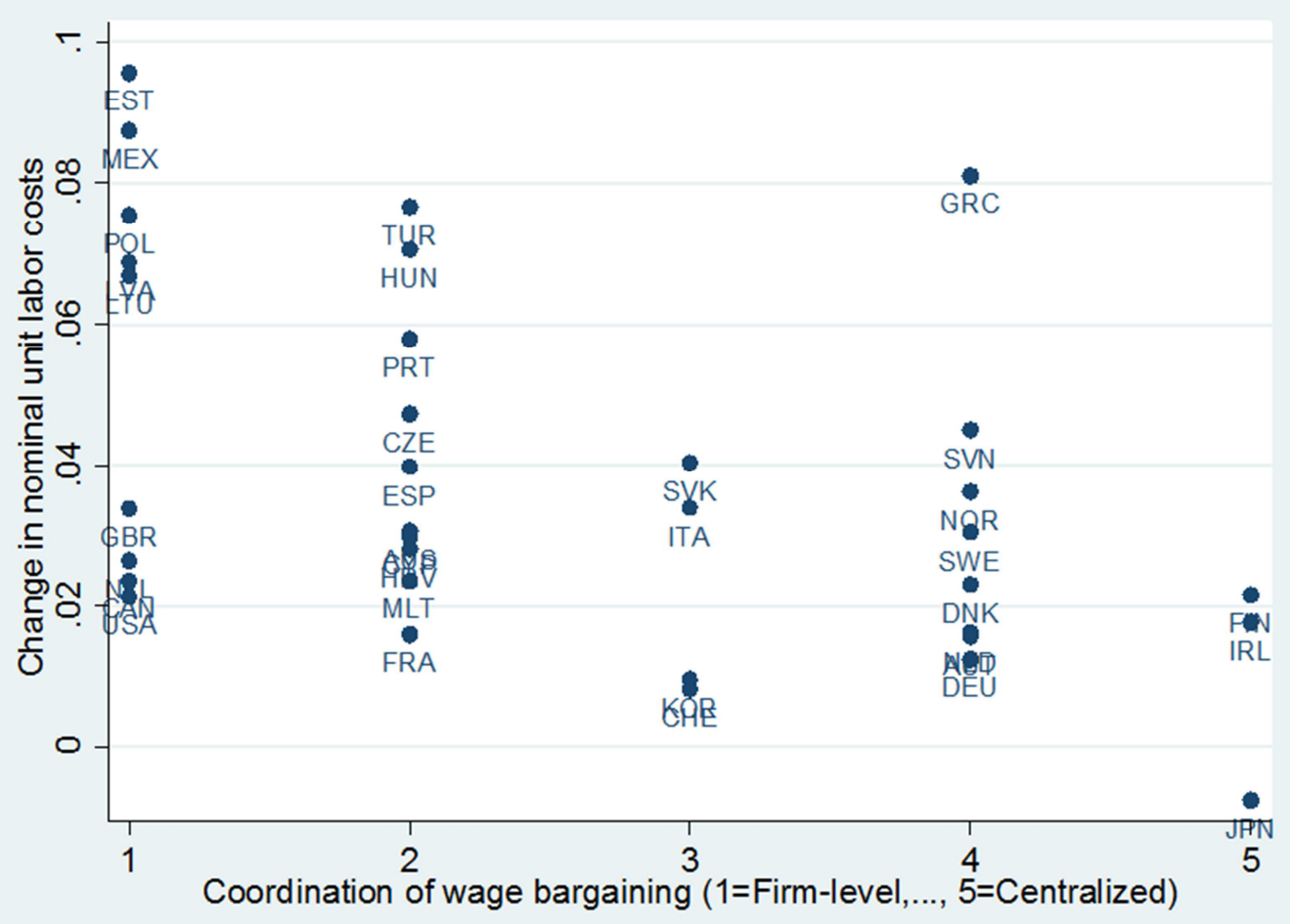

Figure A3. Coordination of wage bargaining and change in nominal unit labor costs (excluding Bulgaria and Romania).

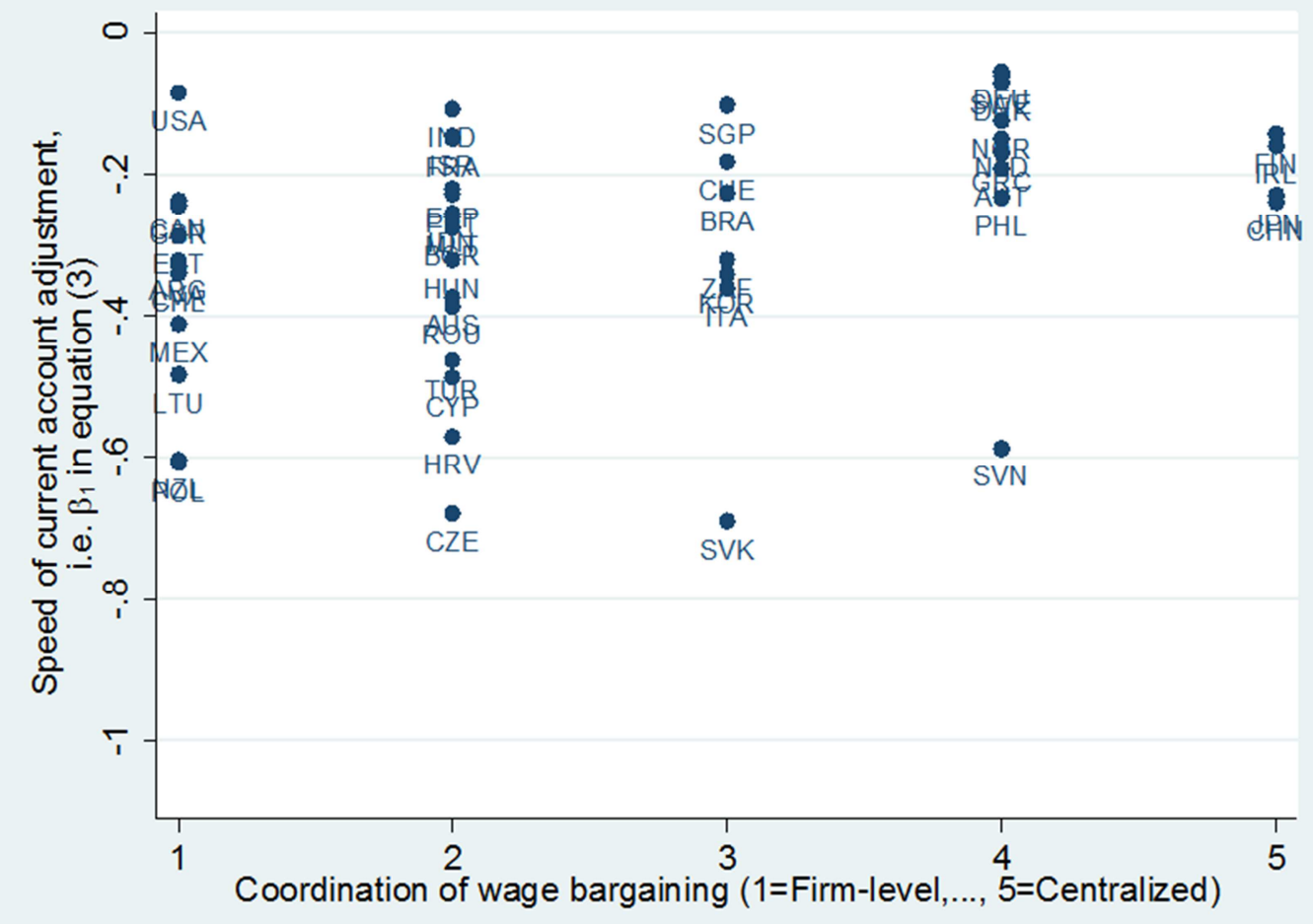

Figure A4. Coordination of wage bargaining and the speed of current account adjustment. 


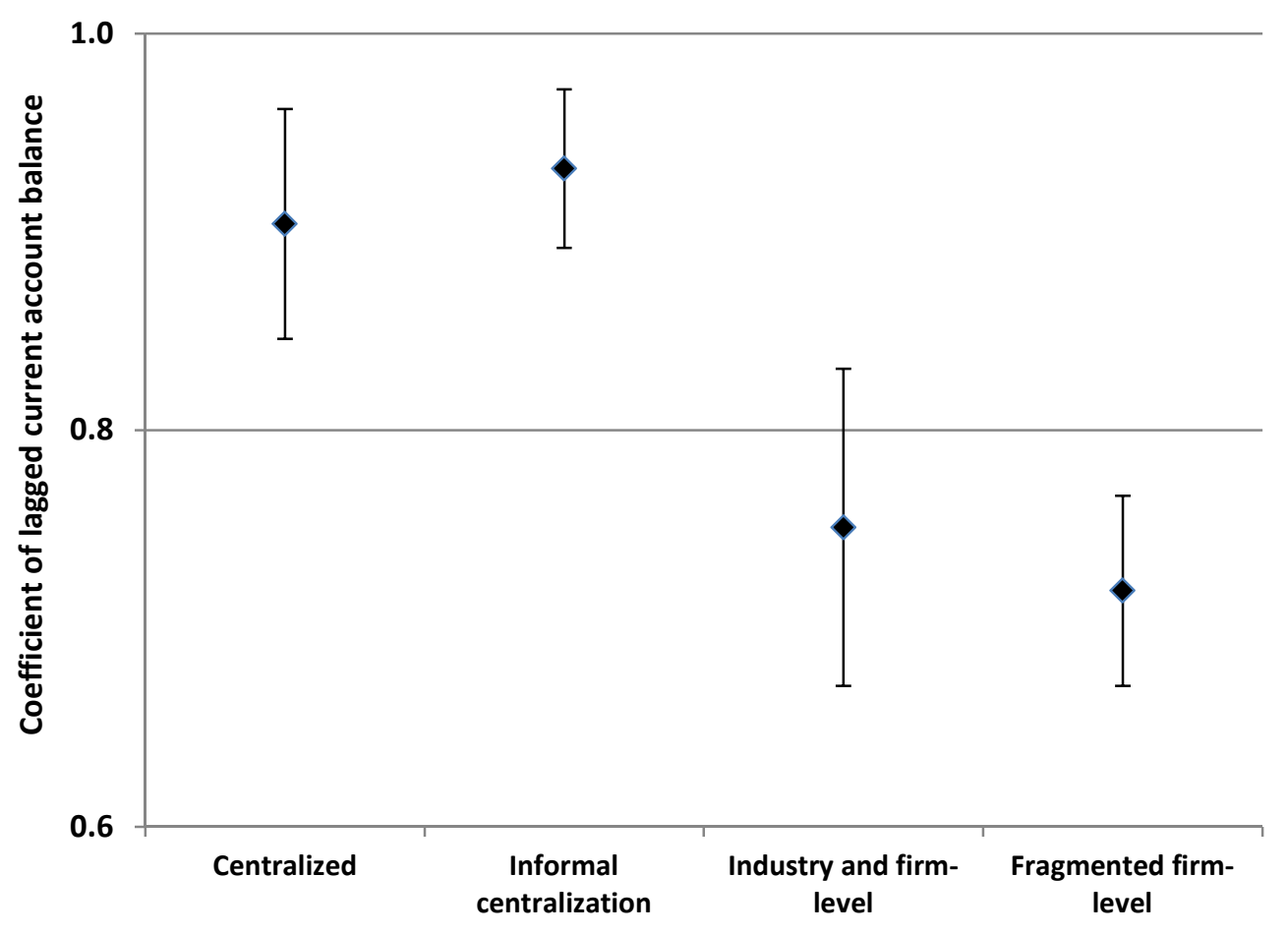

Figure A5. 95\% confidence intervals for $\rho_{1}$ in equation (5). 


\section{Current Accounts and Coordination of Wage Bargaining}

Mika Nieminen, Kari Heimonen, Timo Tohmo

\section{Electronic supplementary material: Additional tables and figures}

Table S1. Coordination of wage bargaining and current account balances, subsamples by IMF country classification

\begin{tabular}{|c|c|c|c|}
\hline Variable & (3ADV) & (3E\&D1) & $(3 \mathrm{E} \& \mathrm{D} 2)$ \\
\hline $\begin{array}{l}\text { Coordination of wage bargaining } \\
(1=\text { Firm-level, .., 5=Centralized })\end{array}$ & $\begin{array}{l}0.019 * * * \\
(0.004)\end{array}$ & $\begin{array}{l}0.005 \\
0.009\end{array}$ & $\begin{array}{l}0.011 \\
(0.007)\end{array}$ \\
\hline Constant & $\begin{array}{l}-0.060 * * * \\
(0.011)\end{array}$ & $\begin{array}{l}-0.033 \\
(0.020)\end{array}$ & $\begin{array}{l}-0.041 * * \\
(0.017)\end{array}$ \\
\hline $\mathrm{R}^{2}$ & 0.285 & 0.039 & 0.166 \\
\hline Observations & 31 & 15 & 14 \\
\hline Regression type & $\begin{array}{l}\text { Cross- } \\
\text { sectional }\end{array}$ & $\begin{array}{l}\text { Cross- } \\
\text { sectional }\end{array}$ & $\begin{array}{l}\text { Cross- } \\
\text { sectional }\end{array}$ \\
\hline
\end{tabular}

Notes: The dependent variable is the long-run current account balance (ratio to GDP). Heteroscedasticity robust standard errors are in parentheses. The sample consists of advanced economies in model (3ADV). The sample consists of emerging market and developing economies in models (3E\&D1)-(3E\&D2). Romania was excluded in model (3E\&D2). *,** and $* * *$ denote statistical significance at the $10 \%, 5 \%$ and $1 \%$ levels. 
Table S2. Coordination of wage bargaining and current account balances

\begin{tabular}{|c|c|c|c|c|c|}
\hline Variable & $(1 \mathrm{~A})$ & $(2 \mathrm{~A})$ & $(3 \mathrm{~A})$ & $(4 \mathrm{~A})$ & $(5 \mathrm{~A})$ \\
\hline \multicolumn{6}{|l|}{ Coordination of wage bargaining: } \\
\hline Industry and firm-level & $\begin{array}{l}0.006 \\
(0.010)\end{array}$ & $\begin{array}{l}0.007 \\
(0.010)\end{array}$ & & $\begin{array}{l}-0.000 \\
(0.008)\end{array}$ & \\
\hline Informal centralization & $\begin{array}{l}0.023 * \\
(0.012)\end{array}$ & $\begin{array}{l}0.023^{*} \\
(0.012)\end{array}$ & & $\begin{array}{l}0.017 * * \\
(0.008)\end{array}$ & \\
\hline Centralized bargaining: & $\begin{array}{l}0.025 * * \\
(0.009)\end{array}$ & & & & \\
\hline $\begin{array}{l}\text { Centralized without } \\
\text { peace obligation }\end{array}$ & & $\begin{array}{l}0.024 * * \\
(0.010)\end{array}$ & & $\begin{array}{l}0.022 * * * \\
(0.008)\end{array}$ & \\
\hline Centralized with & & $0.027 * *$ & & $0.026 * * *$ & \\
\hline peace obligation & & $(0.011)$ & & $(0.009)$ & \\
\hline $\begin{array}{l}\text { Coordination of wage bargaining } \\
(1=\text { Firm-level, } \ldots, 5=\text { Centralized })\end{array}$ & & & $\begin{array}{l}0.008 * * * \\
(0.003)\end{array}$ & & $\begin{array}{l}0.008 * * * \\
(0.002)\end{array}$ \\
\hline GDP per capita & $\begin{array}{l}0.020 * * * \\
(0.003)\end{array}$ & $\begin{array}{l}0.020 * * * \\
(0.003)\end{array}$ & $\begin{array}{l}0.020 * * * \\
(0.003)\end{array}$ & $\begin{array}{l}0.014 * * * \\
(0.003)\end{array}$ & $\begin{array}{l}0.015 * * * \\
(0.003)\end{array}$ \\
\hline Budget balance & $\begin{array}{l}0.491 * * * \\
(0.152)\end{array}$ & $\begin{array}{l}0.493 * * * \\
(0.153)\end{array}$ & $\begin{array}{l}0.519 * * * \\
(0.154)\end{array}$ & $\begin{array}{l}0.222 * * \\
(0.087)\end{array}$ & $\begin{array}{l}0.237 * * \\
(0.089)\end{array}$ \\
\hline Old dependency ratio & $\begin{array}{l}-0.168 * * \\
(0.072)\end{array}$ & $\begin{array}{l}-0.167 * * \\
(0.074)\end{array}$ & $\begin{array}{l}-0.182 * * \\
(0.071)\end{array}$ & $\begin{array}{l}-0.144 * * \\
(0.070)\end{array}$ & $\begin{array}{l}-0.145^{* *} \\
(0.070)\end{array}$ \\
\hline Democratic accountability & $\begin{array}{l}-0.018 * * * \\
(0.005)\end{array}$ & $\begin{array}{l}-0.018 * * * \\
(0.005)\end{array}$ & $\begin{array}{l}-0.018 * * * \\
(0.005)\end{array}$ & $\begin{array}{l}-0.010 * * * \\
(0.003)\end{array}$ & $\begin{array}{l}-0.010^{* * * *} \\
(0.003)\end{array}$ \\
\hline Advanced economy dummy variable & $\begin{array}{l}-0.011 \\
(0.009)\end{array}$ & $\begin{array}{l}-0.011 \\
(0.009)\end{array}$ & $\begin{array}{l}-0.010 \\
(0.009)\end{array}$ & $\begin{array}{l}-0.017 * * \\
(0.008)\end{array}$ & $\begin{array}{l}-0.018 * * \\
(0.009)\end{array}$ \\
\hline Lagged NFA & & & & $\begin{array}{l}0.046^{* * * *} \\
(0.010)\end{array}$ & $\begin{array}{l}0.047 * * * \\
(0.010)\end{array}$ \\
\hline Constant & $\begin{array}{l}0.073 * * * \\
(0.022)\end{array}$ & $\begin{array}{l}0.071 * * * \\
(0.023)\end{array}$ & $\begin{array}{l}0.067 * * \\
(0.026)\end{array}$ & $\begin{array}{l}0.047 * * \\
(0.018)\end{array}$ & $\begin{array}{l}0.041 * * \\
(0.019)\end{array}$ \\
\hline Time effects & & & & Yes & Yes \\
\hline $\mathrm{R}^{2}$ & 0.763 & 0.763 & 0.759 & 0.598 & 0.594 \\
\hline Observations & 46 & 46 & 46 & 935 & 935 \\
\hline Regression type & $\begin{array}{l}\text { Cross- } \\
\text { sectional }\end{array}$ & $\begin{array}{l}\text { Cross- } \\
\text { sectional }\end{array}$ & $\begin{array}{l}\text { Cross- } \\
\text { sectional }\end{array}$ & Panel & Panel \\
\hline
\end{tabular}

Notes: In models (1A)-(3A) the dependent variable is the long-run current account balance (ratio to GDP). Heteroscedasticity robust standard errors are in parentheses. The dependent variable in models (4A)-(5A) is current account balance (ratio to GDP). Panel robust standard errors are in parentheses (clustering on the panel variable). Advanced economy dummy equals one if the country is classified as advanced economy in the IMF's country classification, and zero otherwise. *,** and *** denote statistical significance at the $10 \%, 5 \%$ and $1 \%$ levels. Fragmented firm-level wage coordination is the reference category for the coordination of wage bargaining in models $(1 \mathrm{~A}),(2 \mathrm{~A})$ and $(4 \mathrm{~A})$. The reference category includes 11 countries (models $(1 \mathrm{~A})-(2 \mathrm{~A}))$ or 195 observations (model (4A)). 
Table S3. Coordination of wage bargaining and current account balances

\begin{tabular}{|c|c|c|c|c|}
\hline Variable & (3B) & $(3 \mathrm{C})$ & $(5 \mathrm{~B})$ & $(5 \mathrm{C})$ \\
\hline $\begin{array}{l}\text { Coordination of wage bargaining } \\
(1=\text { Firm-level, } \ldots, 5=\text { Centralized })\end{array}$ & $\begin{array}{l}0.010 * * * \\
(0.003)\end{array}$ & $\begin{array}{l}0.011 * * * \\
(0.003)\end{array}$ & $\begin{array}{l}0.008 * * * \\
(0.002)\end{array}$ & $\begin{array}{l}0.008 * * * \\
(0.002)\end{array}$ \\
\hline Change in nominal unit labor costs & $\begin{array}{l}-0.090 \\
(0.070)\end{array}$ & $\begin{array}{l}-0.074 \\
(0.207)\end{array}$ & $\begin{array}{l}0.010 * * \\
(0.004)\end{array}$ & $\begin{array}{l}-0.203 * * \\
(0.099)\end{array}$ \\
\hline GDP per capita & $\begin{array}{l}0.016 \text { *** } \\
(0.003)\end{array}$ & $\begin{array}{l}0.014 * * * \\
(0.004)\end{array}$ & $\begin{array}{l}0.014 * * * \\
(0.003)\end{array}$ & $\begin{array}{l}0.012 * * * \\
(0.003)\end{array}$ \\
\hline Budget balance & $\begin{array}{l}0.387^{*} \\
(0.195)\end{array}$ & $\begin{array}{l}0.342 * \\
(0.197)\end{array}$ & $\begin{array}{l}0.109 \\
(0.102)\end{array}$ & $\begin{array}{l}0.164 * \\
(0.087)\end{array}$ \\
\hline Old dependency ratio & $\begin{array}{l}-0.083 \\
(0.096)\end{array}$ & $\begin{array}{l}-0.081 \\
(0.089)\end{array}$ & $\begin{array}{l}-0.034 \\
(0.100)\end{array}$ & $\begin{array}{l}-0.048 \\
(0.104)\end{array}$ \\
\hline Democratic accountability & $\begin{array}{l}-0.007 \\
(0.011)\end{array}$ & $\begin{array}{l}0.002 \\
(0.013)\end{array}$ & $\begin{array}{l}-0.002 \\
(0.004)\end{array}$ & $\begin{array}{l}-0.006 \\
(0.006)\end{array}$ \\
\hline Lagged NFA & & & $\begin{array}{l}0.039 * * * \\
(0.012)\end{array}$ & $\begin{array}{l}0.039 * * * \\
(0.012)\end{array}$ \\
\hline Constant & $\begin{array}{l}-0.015 \\
(0.060)\end{array}$ & $\begin{array}{l}-0.064 \\
(0.072)\end{array}$ & $\begin{array}{l}-0.045 \\
(0.037)\end{array}$ & $\begin{array}{l}-0.002 \\
(0.047)\end{array}$ \\
\hline Time effects & & & Yes & Yes \\
\hline $\mathrm{R}^{2}$ & 0.754 & 0.746 & 0.550 & 0.573 \\
\hline Number of countries & 36 & 34 & 724 & 697 \\
\hline Regression type & $\begin{array}{l}\text { Cross- } \\
\text { sectional }\end{array}$ & $\begin{array}{l}\text { Cross- } \\
\text { sectional }\end{array}$ & Panel & Panel \\
\hline
\end{tabular}

Notes: In models (3B)-(3C) the dependent variable is the long-run current account balance (ratio to GDP). Heteroscedasticity robust standard errors are in parentheses. The dependent variable in models $(5 \mathrm{~B})-(5 \mathrm{C})$ is current account balance (ratio to GDP). Panel robust standard errors are in parentheses (clustering on the panel variable). In models (3C) and (5C), the two countries with the largest increase in nominal unit labor costs and the lowest GDP per capita (Bulgaria and Romania) were excluded. *,** and $* * *$ denote statistical significance at the $10 \%, 5 \%$ and $1 \%$ levels. 
Table S4. Coordination of wage bargaining and speed of current account adjustment

\begin{tabular}{|c|c|c|c|c|}
\hline Variable & $(10 \mathrm{~A})$ & $(11 \mathrm{~A})$ & $(12 \mathrm{~A})$ & $(13 \mathrm{~A})$ \\
\hline \multicolumn{5}{|l|}{ Coordination of wage bargaining: } \\
\hline Industry and firm-level & $\begin{array}{l}0.058 \\
(0.072)\end{array}$ & $\begin{array}{l}0.071 \\
(0.072)\end{array}$ & $\begin{array}{l}0.077 \\
(0.070)\end{array}$ & \\
\hline Informal centralization & $\begin{array}{l}0.071 \\
(0.082)\end{array}$ & $\begin{array}{l}0.084 \\
(0.083)\end{array}$ & $\begin{array}{l}0.085 \\
(0.084)\end{array}$ & \\
\hline Centralized bargaining: & $\begin{array}{l}0.164 * * * \\
(0.060)\end{array}$ & $\begin{array}{l}0.188 * * * \\
(0.060)\end{array}$ & & \\
\hline $\begin{array}{l}\text { Centralized without } \\
\text { peace obligation }\end{array}$ & & & $\begin{array}{l}0.188 * * \\
(0.076)\end{array}$ & \\
\hline $\begin{array}{l}\text { Centralized with } \\
\text { peace obligation }\end{array}$ & & & $\begin{array}{l}0.194 * * * \\
(0.056)\end{array}$ & \\
\hline $\begin{array}{l}\text { Coordination of wage bargaining ( } 1=\text { Firm- } \\
\text { level, } \ldots, 5=\text { =Centralized })\end{array}$ & & & & $\begin{array}{l}0.053 * * * \\
(0.016)\end{array}$ \\
\hline Constant & $\begin{array}{l}-0.367 * * * \\
(0.066)\end{array}$ & $\begin{array}{l}-0.390 * * * \\
(0.066)\end{array}$ & $\begin{array}{l}-0.387 * * * \\
(0.068)\end{array}$ & $\begin{array}{l}-0.421 * * * \\
(0.063)\end{array}$ \\
\hline Financial openness & $\begin{array}{l}0.024 \\
(0.023)\end{array}$ & $\begin{array}{l}0.020 \\
(0.023)\end{array}$ & $\begin{array}{l}0.021 \\
(0.023)\end{array}$ & $\begin{array}{l}0.023 \\
(0.021)\end{array}$ \\
\hline Trade openness & $\begin{array}{l}-0.025 \\
(0.063)\end{array}$ & $\begin{array}{l}-0.009 \\
(0.060)\end{array}$ & $\begin{array}{l}-0.012 \\
(0.060)\end{array}$ & $\begin{array}{l}-0.011 \\
(0.057)\end{array}$ \\
\hline Log GDP per capita in the year 2000 & $\begin{array}{l}0.019 \\
(0.025)\end{array}$ & $\begin{array}{l}0.013 \\
(0.024)\end{array}$ & $\begin{array}{l}0.014 \\
(0.024)\end{array}$ & $\begin{array}{l}0.009 \\
(0.025)\end{array}$ \\
\hline GDP per capita growth & $\begin{array}{l}-0.165 \\
(0.968)\end{array}$ & $\begin{array}{l}-0.289 \\
(0.885)\end{array}$ & $\begin{array}{l}-0.358 \\
(0.972)\end{array}$ & $\begin{array}{l}-0.822 \\
(0.867)\end{array}$ \\
\hline US dummy variable & & $\begin{array}{l}0.248 * * * \\
(0.064)\end{array}$ & $\begin{array}{l}0.243 * * * \\
(0.063)\end{array}$ & $\begin{array}{l}0.233 * * * \\
(0.060)\end{array}$ \\
\hline $\mathrm{R}^{2}$ & 0.240 & 0.279 & 0.276 & 0.264 \\
\hline Number of countries & 46 & 46 & 46 & 46 \\
\hline
\end{tabular}

Notes: The dependent variable is a country-specific regression coefficient for an AR process with lags that characterizes the speed of adjustment of the current account toward its long-run equilibrium, i.e. $\beta_{1, \mathrm{i}}$ in equation (3). Heteroscedasticity robust standard errors are in parentheses. * ** and *** denote statistical significance at the $10 \%, 5 \%$ and $1 \%$ levels. Fragmented firm-level wage coordination is the reference category for the coordination of wage bargaining in models (10A)-(12A). The reference category includes 11 countries. 
Table S5. Coordination of wage bargaining and speed of current account adjustment

\begin{tabular}{|c|c|c|c|c|}
\hline Variable & $(10 \mathrm{~B})$ & $(11 \mathrm{~B})$ & $(12 \mathrm{~B})$ & $(13 \mathrm{~B})$ \\
\hline \multicolumn{5}{|l|}{ Coordination of wage bargaining: } \\
\hline Industry and firm-level & $\begin{array}{l}0.012 \\
(0.066)\end{array}$ & $\begin{array}{l}0.039 \\
(0.064)\end{array}$ & $\begin{array}{l}0.040 \\
(0.064)\end{array}$ & \\
\hline Informal centralization & $\begin{array}{l}0.030 \\
(0.088)\end{array}$ & $\begin{array}{l}0.058 \\
(0.086)\end{array}$ & $\begin{array}{l}0.056 \\
(0.088)\end{array}$ & \\
\hline Centralized bargaining: & $\begin{array}{l}0.132 * \\
(0.073)\end{array}$ & $\begin{array}{l}0.159 * * \\
(0.071)\end{array}$ & & \\
\hline $\begin{array}{l}\text { Centralized without } \\
\text { peace obligation }\end{array}$ & & & $\begin{array}{l}0.164 * * \\
(0.082)\end{array}$ & \\
\hline $\begin{array}{l}\text { Centralized with } \\
\text { peace obligation }\end{array}$ & & & $\begin{array}{l}0.148 * * * \\
(0.050)\end{array}$ & \\
\hline $\begin{array}{l}\text { Coordination of wage bargaining ( } 1=\text { Firm- } \\
\text { level,..., } 5=\text { Centralized })\end{array}$ & & & & $\begin{array}{l}0.044 * * \\
(0.017)\end{array}$ \\
\hline Constant & $\begin{array}{l}-0.359 * * * \\
(0.048)\end{array}$ & $\begin{array}{l}-0.386 * * * \\
(0.044)\end{array}$ & $\begin{array}{l}-0.386 * * * \\
(0.045)\end{array}$ & $\begin{array}{l}-0.435 * * * \\
(0.045)\end{array}$ \\
\hline US dummy variable & & $\begin{array}{l}0.302 * * * \\
(0.044)\end{array}$ & $\begin{array}{l}0.302 * * * \\
(0.045)\end{array}$ & $\begin{array}{l}0.306 * * * \\
(0.034)\end{array}$ \\
\hline EMU dummy variable & $\begin{array}{l}0.079 \\
(0.050)\end{array}$ & $\begin{array}{l}0.079 \\
(0.051)\end{array}$ & $\begin{array}{l}0.091 * \\
(0.047)\end{array}$ & $\begin{array}{l}0.098 * * \\
(0.045)\end{array}$ \\
\hline $\mathrm{R}^{2}$ & 0.210 & 0.274 & 0.278 & 0.264 \\
\hline Number of countries & 46 & 46 & 46 & 46 \\
\hline
\end{tabular}

Notes: The dependent variable is a country-specific regression coefficient for an AR process with lags that characterizes the speed of adjustment of the current account toward its long-run equilibrium, i.e. $\beta_{1, \mathrm{i}}$ in equation (3). Heteroscedasticity robust standard errors are in parentheses. EMU dummy equals one, if a country adopted the euro by 2001 and zero otherwise. *,** and *** denote statistical significance at the $10 \%, 5 \%$ and $1 \%$ levels. Fragmented firm-level wage coordination is the reference category for the coordination of wage bargaining in models (10B)-(12B). The reference category includes 11 countries. 
Table S6. Coordination of wage bargaining and speed of current account adjustment, subsamples by IMF country classification

\begin{tabular}{lll}
\hline Variable & $(13 \mathrm{ADV})$ & $(13 \mathrm{E} \& \mathrm{D})$ \\
\hline $\begin{array}{l}\text { Coordination of wage bargaining (1=Firm- } \\
\text { level,..., 5=Centralized) }\end{array}$ & $0.045^{* *}$ & $0.052^{* *}$ \\
& $(0.020)$ & $(0.019)$ \\
Constant & $-0.396^{* * *}$ & $-0.454^{* * *}$ \\
& $(0.067)$ & $(0.068)$ \\
$\mathrm{R}^{2}$ & 0.111 & 0.204 \\
Number of countries & 31 & 15 \\
\hline
\end{tabular}

Notes: The dependent variable is a country-specific regression coefficient for an AR process with lags that characterizes the speed of adjustment of the current account toward its long-run equilibrium, i.e. $\beta_{1, \mathrm{i}}$ in equation (3). Heteroscedasticity robust standard errors are in parentheses. In model (13ADV), the sample consists of advanced economies. In model (13E\&D), the sample consists of emerging market and developing economies.*, $* *$ and $* * *$ denote statistical significance at the $10 \%, 5 \%$ and $1 \%$ levels.

Table S7. Coordination of wage bargaining and rate of current account reversion

\begin{tabular}{|c|c|c|c|c|}
\hline \multirow[b]{3}{*}{ Variable } & $(14 \mathrm{~A})$ & $(15 \mathrm{~A})$ & $(16 \mathrm{~A})$ & $(17 \mathrm{~A})$ \\
\hline & \multicolumn{4}{|c|}{ Coordination of wage bargaining: } \\
\hline & Centralized & $\begin{array}{l}\text { Informal } \\
\text { centralization }\end{array}$ & $\begin{array}{l}\text { Industry and } \\
\text { firm-level }\end{array}$ & $\begin{array}{l}\text { Fragmented } \\
\text { firm-level }\end{array}$ \\
\hline $\mathrm{CA}_{\mathrm{t}-1}$ & $\begin{array}{l}0.906 * * * \\
(0.029)\end{array}$ & $\begin{array}{l}0.909 * * * \\
(0.030)\end{array}$ & $\begin{array}{l}0.762 * * * \\
(0.044)\end{array}$ & $\begin{array}{l}0.719 * * * \\
(0.023)\end{array}$ \\
\hline Financial Openness & $\begin{array}{l}-0.000 \\
(0.001)\end{array}$ & $\begin{array}{l}0.004 * * \\
(0.001)\end{array}$ & $\begin{array}{l}-0.000 \\
(0.001)\end{array}$ & $\begin{array}{l}0.000 \\
(0.001)\end{array}$ \\
\hline $\mathrm{R}^{2}$ & 0.818 & 0.836 & 0.613 & 0.520 \\
\hline Observations & 423 & 247 & 312 & 256 \\
\hline
\end{tabular}

All regressions include a constant.

Notes: The dependent variable is current account balance (ratio to GDP). $\mathrm{CA}_{\mathrm{t}-1}$ is the lagged term of current account balance. Panel robust standard errors are in parentheses (clustering on the panel variable). *, ** and $* * *$ denote statistical significance at the $10 \%, 5 \%$ and $1 \%$ levels. 
Table S8. Coordination of wage bargaining and the rate of current account reversion

\begin{tabular}{|c|c|c|}
\hline Variable & $(18 \mathrm{~A})$ & (19A) \\
\hline $\mathrm{CA}_{\mathrm{t}-1}$ & $\begin{array}{l}0.719 * * * \\
(0.022)\end{array}$ & $\begin{array}{l}0.695 * * * \\
(0.059)\end{array}$ \\
\hline $\mathrm{CA}_{\mathrm{t}-1} \mathrm{x}$ Industry and firm-level bargaining & $\begin{array}{l}0.048 \\
(0.050)\end{array}$ & \\
\hline $\mathrm{CA}_{\mathrm{t}-1} \mathrm{x}$ Informal centralization & $\begin{array}{l}0.222 * * * \\
(0.033)\end{array}$ & \\
\hline $\mathrm{CA}_{\mathrm{t}-1} \mathrm{x}$ Centralized bargaining & $\begin{array}{l}0.180 * * * \\
(0.038)\end{array}$ & \\
\hline $\mathrm{CA}_{\mathrm{t}-1} \mathrm{x}$ Coordination of wage bargaining & & $\begin{array}{l}0.061 * * * \\
(0.016)\end{array}$ \\
\hline \multicolumn{3}{|l|}{ Coordination of wage bargaining: } \\
\hline Industry and firm-level & $\begin{array}{l}0.001 \\
(0.003)\end{array}$ & \\
\hline Informal centralization & $\begin{array}{l}0.009 * * * \\
(0.003)\end{array}$ & \\
\hline Centralized bargaining & $\begin{array}{l}0.010 * * * \\
(0.003)\end{array}$ & \\
\hline $\begin{array}{l}\text { Coordination of wage bargaining } \\
(1=\text { Firm-level, } \ldots, 4=\text { Centralized })\end{array}$ & & $\begin{array}{l}0.003 * * * \\
(0.001)\end{array}$ \\
\hline Financial Openness & $\begin{array}{l}0.001 \\
(0.001)\end{array}$ & $\begin{array}{l}0.001 * * \\
(0.000)\end{array}$ \\
\hline Constant & $\begin{array}{l}-0.009 * * * \\
(0.002)\end{array}$ & $\begin{array}{l}-0.012 * * * \\
(0.003)\end{array}$ \\
\hline $\mathrm{R}^{2}$ & 0.783 & 0.780 \\
\hline Observations & 1238 & 1238 \\
\hline
\end{tabular}

Notes: The dependent variable is current account balance (ratio to GDP). Panel robust standard errors are in parentheses (clustering on the panel variable). ${ }^{*}, * *$ and $* * *$ denote statistical significance at the $10 \%, 5 \%$ and $1 \%$ levels. Fragmented firm-level wage coordination is the reference category for the coordination of wage bargaining in model (18A). The reference category includes 256 observations. 
Table S9. Coordination of wage bargaining, exchange rate stability and speed of current account adjustment

\begin{tabular}{|c|c|c|}
\hline Variable & $(24 \mathrm{~A})$ & $(25 \mathrm{~A})$ \\
\hline \multicolumn{3}{|l|}{ Coordination of wage bargaining: } \\
\hline Industry and firm-level & $\begin{array}{l}0.093 \\
(0.180)\end{array}$ & \\
\hline Informal centralization & $\begin{array}{l}0.583 * * * \\
(0.167)\end{array}$ & \\
\hline Centralized bargaining: & $\begin{array}{l}0.470 * * * \\
(0.170)\end{array}$ & \\
\hline $\begin{array}{l}\text { Coordination of wage bargaining } \\
(1=\text { Firm-level, ..., 4=Centralized })\end{array}$ & & $\begin{array}{l}0.147 * * * \\
(0.051)\end{array}$ \\
\hline \multicolumn{3}{|c|}{$\begin{array}{l}\text { Interaction between Coordination of wage bargaining and Exchange } \\
\text { rate stability: }\end{array}$} \\
\hline $\begin{array}{l}\text { Industry and firm-level wage bargaining } x \\
\text { Exchange rate stability }\end{array}$ & $\begin{array}{l}-0.118 \\
(0.335)\end{array}$ & \\
\hline $\begin{array}{l}\text { Informal centralization } \mathrm{x} \\
\text { Exchange rate stability }\end{array}$ & $\begin{array}{l}-1.115^{* * *} \\
(0.385)\end{array}$ & \\
\hline $\begin{array}{l}\text { Centralized wage bargaining } \mathrm{x} \\
\text { Exchange rate stability }\end{array}$ & $\begin{array}{l}-0.626 * \\
(0.328)\end{array}$ & \\
\hline $\begin{array}{l}\text { Coordination of wage bargaining } \mathrm{x} \\
\text { Exchange rate stability }\end{array}$ & & $\begin{array}{l}-0.189 * \\
(0.096)\end{array}$ \\
\hline Exchange rate stability & $\begin{array}{l}0.525^{*} \\
(0.287)\end{array}$ & $\begin{array}{l}0.660 * * \\
(0.316)\end{array}$ \\
\hline Financial Openness & $\begin{array}{l}0.009 \\
(0.023)\end{array}$ & $\begin{array}{l}0.014 \\
(0.020)\end{array}$ \\
\hline Log GDP per capita in the year 2000 & $\begin{array}{l}0.018 \\
(0.025)\end{array}$ & $\begin{array}{l}0.014 \\
(0.023)\end{array}$ \\
\hline Constant & $\begin{array}{l}-0.615 * * * \\
(0.137)\end{array}$ & $\begin{array}{l}-0.760 * * * \\
(0.154)\end{array}$ \\
\hline $\mathrm{R}^{2}$ & 0.340 & 0.289 \\
\hline Number of countries & 45 & 45 \\
\hline
\end{tabular}

Notes: The dependent variable is a country-specific regression coefficient for an AR process with lags that characterizes the speed of adjustment of the current account toward its long-run equilibrium, i.e. $\beta 1, i$ in equation (3). Heteroscedasticity robust standard errors are in parentheses. *, ** and *** denote statistical significance at the $10 \%, 5 \%$ and $1 \%$ levels. Fragmented firm-level wage coordination is the reference category for the coordination of wage bargaining in model (24A). The reference category includes 10 countries. 
Table S10. Coordination of wage bargaining, exchange rate stability and speed of current account adjustment

\begin{tabular}{|c|c|c|}
\hline Variable & $(24 B)$ & $(25 \mathrm{~B})$ \\
\hline \multicolumn{3}{|l|}{ Coordination of wage bargaining: } \\
\hline Industry and firm-level & $\begin{array}{l}0.126 \\
(0.196)\end{array}$ & \\
\hline Informal centralization & $\begin{array}{l}0.645 * * * \\
(0.180)\end{array}$ & \\
\hline Centralized bargaining: & $\begin{array}{l}0.517 * * * \\
(0.160)\end{array}$ & \\
\hline $\begin{array}{l}\text { Coordination of wage bargaining } \\
(1=\text { Firm-level, .., 4=Centralized })\end{array}$ & & $\begin{array}{l}0.160 * * * \\
(0.052)\end{array}$ \\
\hline \multicolumn{3}{|c|}{$\begin{array}{l}\text { Interaction between Coordination of wage bargaining and Exchange } \\
\text { rate stability: }\end{array}$} \\
\hline $\begin{array}{l}\text { Industry and firm-level wage bargaining } \mathrm{x} \\
\text { Exchange rate stability }\end{array}$ & $\begin{array}{l}-0.250 \\
(0.382)\end{array}$ & \\
\hline $\begin{array}{l}\text { Informal centralization } \mathrm{x} \\
\text { Exchange rate stability }\end{array}$ & $\begin{array}{l}-1.278 * * * \\
(0.413)\end{array}$ & \\
\hline $\begin{array}{l}\text { Centralized wage bargaining } \mathrm{x} \\
\text { Exchange rate stability }\end{array}$ & $\begin{array}{l}-0.775^{* *} \\
(0.324)\end{array}$ & \\
\hline $\begin{array}{l}\text { Coordination of wage bargaining } \mathrm{x} \\
\text { Exchange rate stability }\end{array}$ & & $\begin{array}{l}-0.216 * * \\
(0.091)\end{array}$ \\
\hline Exchange rate stability & $\begin{array}{l}0.551^{*} \\
(0.288)\end{array}$ & $\begin{array}{l}0.648 * * \\
(0.307)\end{array}$ \\
\hline EMU dummy variable & $\begin{array}{l}0.098 \\
(0.066)\end{array}$ & $\begin{array}{l}0.085 \\
(0.059)\end{array}$ \\
\hline Constant & $\begin{array}{l}-0.621 * * * \\
(0.146)\end{array}$ & $\begin{array}{l}-0.754 * * * \\
(0.172)\end{array}$ \\
\hline $\mathrm{R}^{2}$ & 0.352 & 0.287 \\
\hline Number of countries & 45 & 45 \\
\hline
\end{tabular}

Notes: The dependent variable is a country-specific regression coefficient for an AR process with lags that characterizes the speed of adjustment of the current account toward its long-run equilibrium, i.e. $\beta 1$, $i$ in equation (3). Heteroscedasticity robust standard errors are in parentheses. *, ** and *** denote statistical significance at the $10 \%, 5 \%$ and $1 \%$ levels. Fragmented firm-level wage coordination is the reference category for the coordination of wage bargaining in model (24B). The reference category includes 10 countries. 


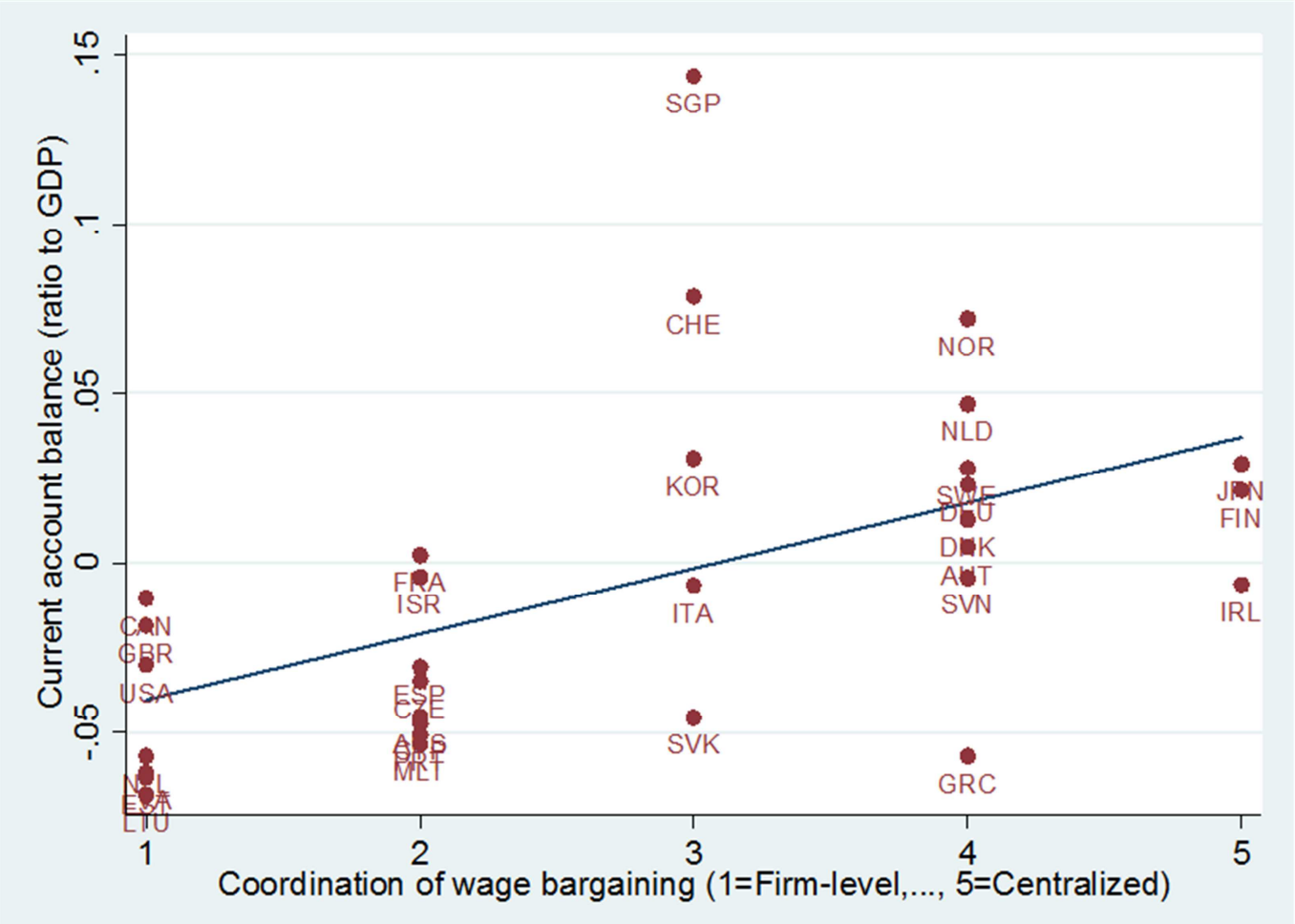

Figure S1. Coordination of wage bargaining and long-run current account balance, advanced economies sample, model (3ADV).

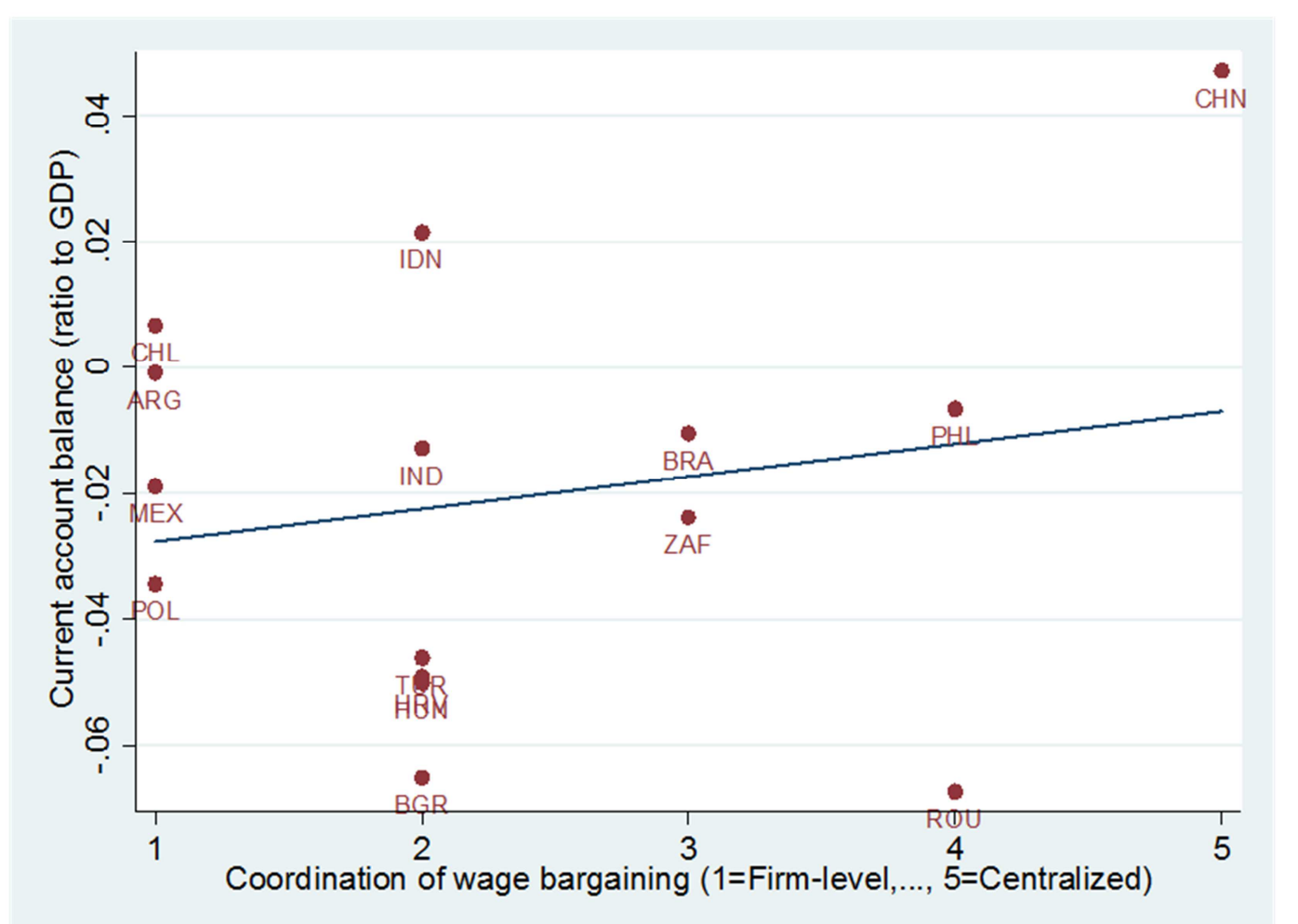

Figure S2. Coordination of wage bargaining and long-run current account balance, emerging market and developing economies sample, model (3E\&D1). 


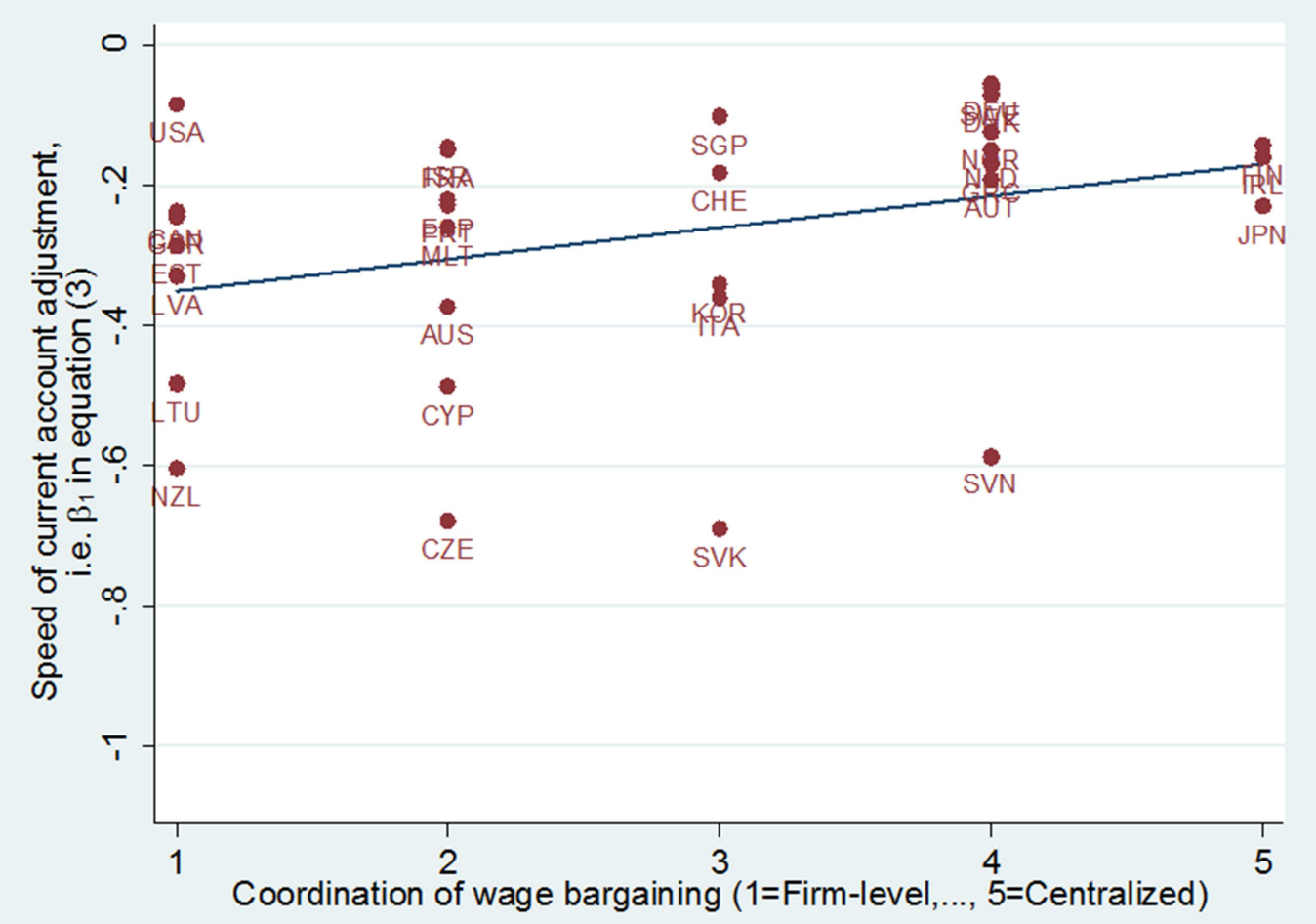

Figure S3. Coordination of wage bargaining and the speed of current account adjustment, advanced economies sample, model (13ADV).

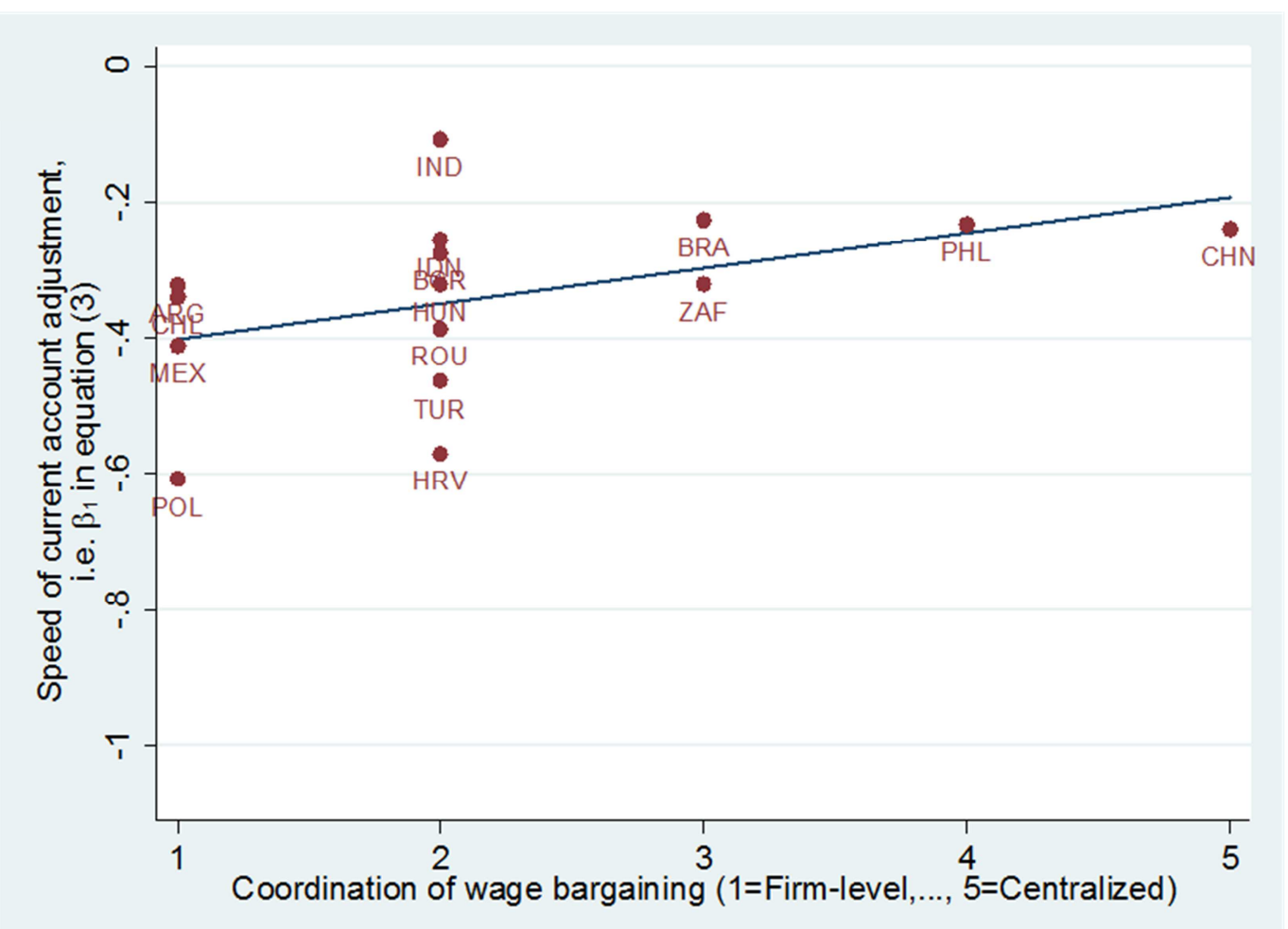

Figure S4. Coordination of wage bargaining and speed of current account adjustment, emerging market and developing economies sample, model (13E\&D). 